This item was submitted to Loughborough's Research Repository by the author.

Items in Figshare are protected by copyright, with all rights reserved, unless otherwise indicated.

\title{
Wage gradients in an enlarged EU.
}

PLEASE CITE THE PUBLISHED VERSION

LICENCE

CC BY-NC-ND 4.0

\section{REPOSITORY RECORD}

Marques, Helena, and Hugh Metcalf. 2019. "Wage Gradients in an Enlarged EU.”. figshare. https://hdl.handle.net/2134/183. 
This item was submitted to Loughborough's Institutional Repository by the author and is made available under the following Creative Commons Licence conditions.

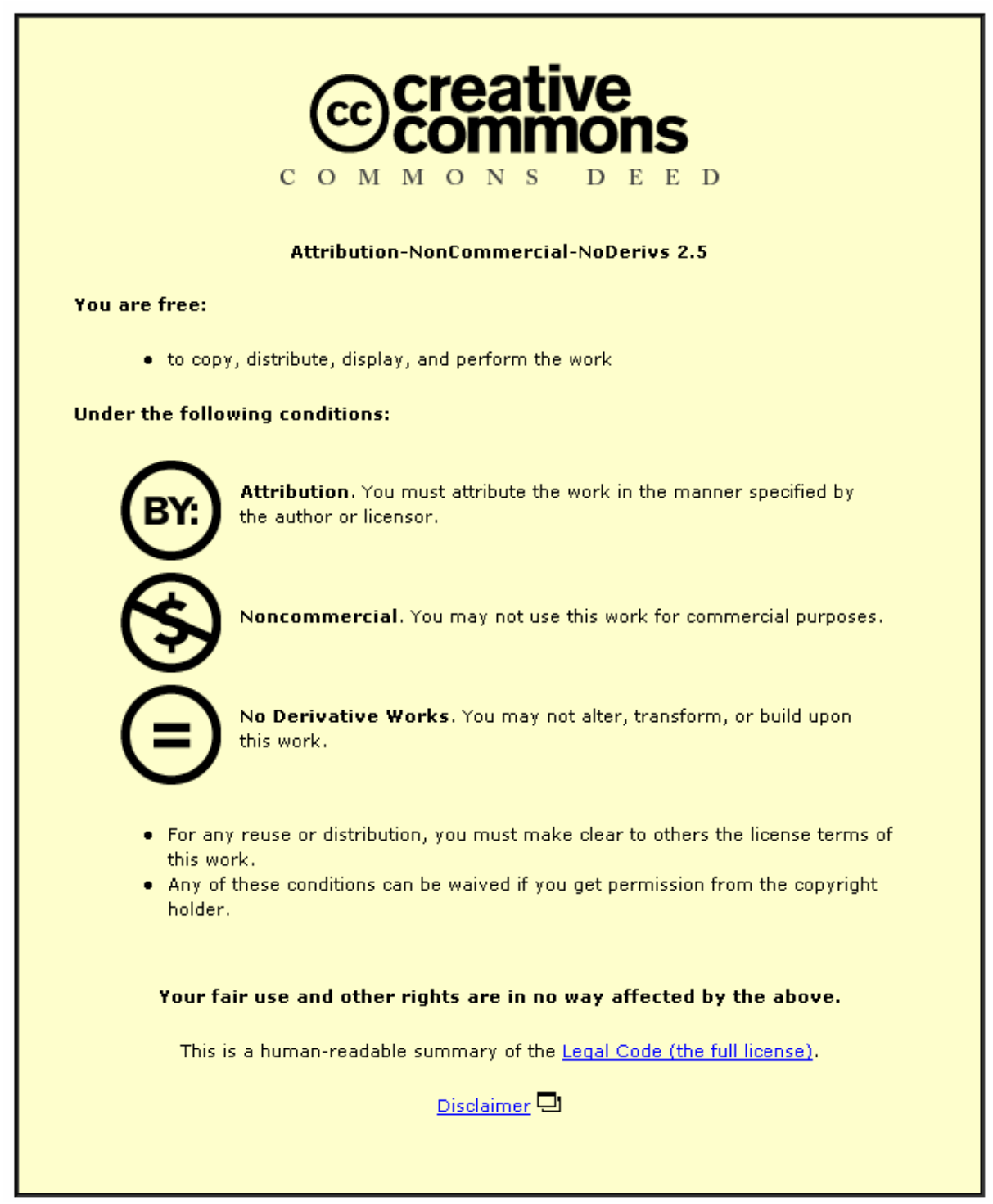

For the full text of this licence, please go to: http://creativecommons.org/licenses/by-nc-nd/2.5/ 


\title{
Wage Gradients in an Enlarged EU
}

\author{
Helena Marques 1 and Hugh Metcalf 2
}

\begin{abstract}
In this paper we estimate a sectoral real wage equation for three regional blocs of the enlarged EU that we defined as North (wealthiest EU), South (Greece, Portugal and Spain) and East (acceding Central and Eastern European countries). The estimation results show that real wages react differently in each of the blocs to the impact of market size, location and factor endowments across a range of industrial sectors which differ by their degrees of economies of scale and skill-intensities in the presence of transport costs.
\end{abstract}

Keywords: wage equation, labour demand, human capital, EU enlargement JEL: F15, F22, J31, L6

\footnotetext{
1 Department of Economics, Sir Richard Morris Building, Loughborough University, Loughborough, LE11 3TU, UK. Corresponding author: H.I.Marques@lboro.ac.uk.

2 Economics Unit, Ridley Building, University of Newcastle upon Tyne Business School, University of Newcastle upon Tyne, Newcastle upon Tyne, NE1 7RU, UK.
} 


\section{Introduction}

The Eastern enlargement of the EU will be a reality in less than one year's time. Ten countries will become members of one of the largest economic blocs in the world and two more (Bulgaria and Romania) may be admitted by 2007. Thus, except for the Mediterranean islands of Cyprus and Malta, the new members will be Central and Eastern European Countries (CEECs). 3 The real wages in these countries are on average five times lower than in Greece, Portugal and Spain, and ten times lower than in the wealthiest EU countries. This begs the question as to what will be the impact of the accession on real wages of both the existing and new members of the EU.

Empirical applications of NEG models usually test particular relationships derived from complex theoretical models. 4 One of those relationships is a wage equation where wages are a function of market and supplier access and also of access to a pool of skilled workers. In turn these variables are distance-weighted averages of incomes and human capital using distance coefficients taken from a gravity model. This relationship has been tested at an aggregated level for NAFTA by Hanson $(1997,1998)$ and in a worldwide context by Redding and Venables (2001) and Venables (2001). These studies conclude that nominal wages increase with proximity to markets and suppliers. Venables (2001) finds two separate European wage gradients, one from the EU core to Greece, Portugal and Spain, and another from Western to Eastern Europe. Using regional data for respectively Canada and the UK, Hunt and Mueller (2002) and Monastiriotis (2002) conclude that regions with more human capital tend to have higher average wages.

Our paper tests a real wage equation where real wages depend on access to both goods and factor markets, in particular to a pool of skilled workers. However, our study differs from the previous ones in several ways. First, we think of the EU as composed of three groups: a core of wealthier countries (North) and two peripheries, one in the South (Greece, Portugal and Spain) and another in the East (new member countries). Second, we conduct a sectoral study of industrial sectors with different degrees of scale economies and skill-intensity in the countries of an enlarged EU-25. Third, we extend the concept of market and supplier access to include productivity spillovers from both markets and suppliers. Finally, we use a panel of transition data with an estimation structure (Panel Corrected Standard Errors) that allows for country-specific variances and country-pairspecific covariances in unbalanced panels. The panel structure provides a larger dataset without eliminating the time-series dimension in the data.

\footnotetext{
3 In the paper we refer to CEECs, or alternatively to EU-East, as being the group formed by Czech Republic, Estonia, Hungary, Latvia, Lithuania, Poland, Slovak Republic, Slovenia, and, on the assumption that they will effectively join the EU, Bulgaria and Romania.

${ }^{4}$ For a thorough survey of empirical work within the NEG framework see Overman et al. (2001).
} 
Our main findings can be summarised as follows. Though the overall relationship between either size, endowments or productivity in each of the markets and real wages is positive, these react more to size, less to endowments and even less to productivity.

These reactions, when significant, also differ among countries and sectors when we jointly regress real wages. In the North, as would be anticipated, real wages react positively to the size of the home market, size and skill of suppliers and negatively to market access. However, surprisingly they also react negatively to the level of their own and their markets endowments, and their own productivity and activity rate. It appears in this mature market that competition amongst factors reduces the real wage level.

In the South, real wages react positively only to access to markets and suppliers, and react negatively to the size of the home market, the productivity of markets, and unemployment. For these countries competition in the goods markets seems to be the overriding force in mitigating real wage increases.

In the East, real wages react positively to the size of the home market, market access in high scale sectors, supplier access, own endowments and productivity, as would be expected. However, they also react positively to unemployment and activity rates, which is taken to be a product of the transition to a market based economy. They react negatively to market access in low scale sectors, endowments and productivity of markets and suppliers, indicating that the impact of competition, from albeit higher real wage economies, is of real concern to these economies.

These findings support the approach that is being taken by the EU in offering a mix of policy measures encompassing income, education and skills together with infrastructure development as each of the regions has a different wage reaction function.

In Section 2 we show how sectoral real wages correlate with access to the goods and labour markets across the EU-25 countries. Section 3 presents the empirical wage equation and Section 4 provides the estimation results. Section 5 concludes. 


\section{Data Features}

Some of the explanatory variables in our model are weighted averages either of the sample countries' GDPs, human capital endowments or productivity. These variables were constructed using as weights distances and distance coefficients taken from a gravity model. This formulation goes back to Harris (1954), who defined the distance-weighted average of incomes as a market potential function, this is, the potential demand for goods produced in a certain location is the sum of the purchasing power in all other locations weighted by transport costs (and these are a function of distance). Redding and Venables (2001) and Venables (2001) propose the use of two concepts, market access and supplier access, that use distance coefficients taken out of respectively export and import gravity equations. Accordingly, countries have access to a market where to place their goods while exporters and a market where to draw inputs from while importers. We have added a further element to account for the level of productivity of firms in each market, once again weighted by the distance coefficients. If firms in an export market have a high level of productivity they will be able to compete more effectively, whilst suppliers from these countries will offer more competitively priced inputs.

We recognise this formulation as a convenient way of testing empirically the presence of backward and forward linkages. For a country $i$ with neighbour country $j$ in sector $k$ and year $t$ the variables can be formalised as follows:

$$
\begin{aligned}
& \widehat{M A}_{i k t}=\sum_{j} \operatorname{GDP}_{j} d_{i j k}^{-\alpha_{x}} \\
& \widehat{H K M A}_{i k t}=\sum_{j} H K_{j} d_{i j k}^{-\alpha_{x}} \\
& \widehat{P R M A}_{i k t}=\sum_{j} P R_{j k} d_{i j k}^{-\alpha_{x}}
\end{aligned}
$$

$$
\begin{aligned}
& \widehat{S A}_{j k t}=\sum_{i} G P_{i} d_{i j k}^{-\alpha_{M}} \\
& \widehat{H K S A}_{j k t}=\sum_{i} H K_{i} d_{i j k}^{-\alpha_{M}} \\
& \widehat{P R S A}_{j k t}=\sum_{i} P R_{i k} d_{i j k}^{-\alpha_{M}}
\end{aligned}
$$

where MA and SA stand for market and supplier access in the goods markets, proxied by the gross domestic product (GDP), HKMA and HKSA represent market and supplier access in the human capital (HK) markets, PRMA and PRSA measure the access to productive markets and suppliers, $d$ is distance and the $\alpha$ 's are distance coefficients ( $X$ for exports and $M$ for imports). These $\alpha$ coefficients are taken from Marques and Metcalf (2003) and given in Appendix A. They result from bilateral gravity equations between the North-South, North-East and South-East country pairs. The bilateral flows within each country group were not included in the regressions. Thus to be able to compute the variables in equations (1) (4) we use the assumption that the distance coefficient between two countries belonging to the same group is given by -1 . 
In Appendix C (Figs. 1, 2 and 3) we show the scatter plots of sectoral real wages against respectively the average of (1) and (2) (Fig. 1), the average of (3) and (4) (Fig. 2), and the average of (5) and (6) (Fig. 3) for each of the North, South and East country groups in the period 1990-995 On the whole, the plots constitute preliminary evidence that the relationship between real wages and access to goods and factors markets, as well as access to productive environments, tends to be positive. This is true even for those industrial sectors with a smaller degree of economies of scale and a lower skill-intensity, such as Leather \& Footwear, Minerals and Textiles \& Clothing. On the whole, real wages react more to scale than to skill, and react even less to the neighbours' productivity. This is because the latter contains two conflicting effects. One is a positive effect through productivity spillovers that increase real wages. Another is a negative effect operating through competition from productive neighbours that decreases real wages. The final outcome depends on the relative magnitude of these effects.

There are also substantial differences among country groups. In the North (Figs. 1A and 2A) real wages tend to increase with access to goods and factors markets in all sectors and countries. This group is the most developed economically and has achieved a greater sectoral balance. A similar picture appears in Fig. 3A, with neighbour's productivity enhancing real wages, except in Minerals, where a clear relationship does not seem to exist.

In the South (Figs. 1B and 2B), the impact of market access on real wages considerably differs across sectors. In particular, real wages in the low scale, low skill sectors react less to market access and to access to human capital than other sectors. On one hand, given their low scale requirements they benefit less from larger markets for final goods and inputs. On the other hand, given their low skill requirements they also benefit less from access to skilled workers both at the forward and backward level. There is also a divide within the group, with real wages in Portugal and Greece lagging behind Spain, even though market access and especially access to human capital increased during the 1990s. This effect is particularly noticeable in Portugal: as a result of building up human capital, in the late 1990s the wage returns were high and there was a fast catching-up. On the contrary, Greece was less dynamic over the period. In all three Southern countries there was a dramatic increase in productivity during the 1990s (Fig. 3B). However, the productivity gains were hardly reflected on the real wages of Spain and Greece, which remained almost static. On the contrary, real wages in Portugal generally responded to productivity gains. Still, and despite similar productivity levels, Spanish real wages remained the highest in the group. 
Perhaps the most surprising results can be found in the East (Figs. $1 \mathrm{C}$ and $2 \mathrm{C}$ ), where the reaction of real wages to goods markets access greatly differs from the reaction to human capital markets. The former is positive and similar across sectors. On the contrary, the latter turns negative for Leather \& Footwear, Metals, Textiles \& Clothing, and Wood Products. The two most salient common factors among these sectors are the low share of FDI and the high unskilled to skilled labour ratio, once physical capital is controlled for (Baldwin et al. (2000). This higher ratio means a higher number of unskilled workers employed per extra skilled worker and thus decreases the average real wage in the sector. In addition, the lower presence of foreign firms also decrease the average productivity in the sector and thus pulls down wages. Similarly to the South, the East seems to be a two-tier group. Those countries lying above the regression line have higher real wages and increasing with access to goods and factors markets: Czech Republic, Hungary, Poland, Slovakia, Slovenia. The countries lying below the regression line have lower real wages and many times decreasing with access to goods and, especially, factors markets: Bulgaria, Latvia, Lithuania, Romania. Estonia is a special case, with intermediate real wages and the lowest access to goods and factors markets. The reason for this probably lies in its remoteness and reduced size, as well as the reduced size of its nearest neighbours.

The East differs from North and South in that it shows the highest reactions of real wages to productivity gains (Fig. 3C) in sectors traditionally strong before transition, such as Chemicals, Machinery, Metals and Minerals. This result is not surprising, as the initial level of productivity was low and transition made wages responsive to market signals. However, in sectors that benefited from either high levels of FDI (e.g., Transport Equipment) or were subject to a substantial amount of outsourcing (e.g., Leather\&Footwear, Textiles\&Clothing, Wood Products), real wages were unresponsive to productivity gains. Here international competitiveness through low wages was the most important factor. The data clearly shows a divide between pre-transition and post-transition sectors. Unfortunately we only have sectoral productivity data for three Eastern countries: Czech Republic, Hungary and Poland. However, even among these there are differences in behaviour: whereas Czech and Polish real wages tend to increase with productivity, Hungarian real wages have in fact decreased! More detailed information on the economies of these countries would be necessary in order to explain this difference. However, such is not the purpose of the present paper and in what follows we look at the Eastern group as an aggregate.

\footnotetext{
5 The sectors represented in both figures from the top left corner to the bottom right corner are: Chemicals (chem), Leather \& Footwear (leat), Machinery (mach), Metals (meta), Minerals (mine), Textiles \& Clothing (text), Transport Equipment (trans) and Wood Products (wood). A fuller description of the build up of these aggregates is provided in Appendix B.
} 


\section{A Sectoral Wage Equation}

In this section explore country and sector differences further through formal econometric analysis. To that end we present an empirical model of the EU-25 based on the relationship between real wages and goods and factors market potentials at a sectoral level. In a NEG setting, real wages change as a result of three conflicting effects. First, the home market effect: wages are higher in the larger markets. This is an agglomeration force. Second, the competition effect: there is less competition in goods and factor markets in the less industrialized markets, thus wages can be fixed at a higher level. This is a dispersion force. Third, the price index effect: scale economies and lower trade costs decrease the price index of the larger markets, increasing their real wages. This is an agglomeration force. From the interaction of these three effects two possibilities arise. If real wages change inversely with the access to markets and suppliers, whenever the latter increases there will be an outflow of workers and/or an inflow of firms. This is an equilibrating mechanism that reduces wage disparities, allowing for convergence. On the contrary, if real wages change proportionately with the access to markets and suppliers, there will be an inflow of workers and/or an outflow of firms and agglomeration follows.

This study applies Hanson's procedure to the EU-25. We directly test wages gradients using a panel dataset. We believe this is the first econometric study of such relationship in the context of an enlarged EU and at a sectoral level. This is the more important in a highly heterogeneous group of 25 countries that have very different real wages and in which we can expect a differentiated behaviour of industrial sectors with different characteristics. The equation to estimate for country $i$, sector $\mathrm{k}$, year $\mathrm{t}$ is given by 6

$$
\begin{aligned}
& \ln \left(\frac{W_{i k t}}{P_{i k t}}\right)=\beta_{0}+\beta_{1} \ln \left(\mathrm{GDP}_{i t}\right)+\beta_{2} \ln \left(\widehat{M A}_{i k t}\right)+\beta_{3} \ln \left(\widehat{S A}_{i k t}\right)+\beta_{4} \ln \left(\mathrm{HK}_{i t}\right)+ \\
& +\beta_{5} \ln \left(\widehat{H K M A}_{i k t}\right)+\beta_{6} \ln \left(\widehat{H K S A}_{i k t}\right)+\beta_{7} \ln \left(\mathrm{U}_{i t}\right)+\beta_{8} \ln \left(\mathrm{AC}_{i t}\right)+ \\
& +\beta_{9} \ln \left(\mathrm{PR}_{\mathrm{ikt}}\right)+\beta_{10} \ln \left(\widehat{\mathrm{PRMA}}_{\mathrm{ikt}}\right)+\beta_{11} \ln \left(\widehat{\mathrm{PRSA}}_{\mathrm{ikt}}\right)+\alpha_{\mathrm{i}}+\mu_{\mathrm{ikt}}
\end{aligned}
$$

with $\mathrm{W}$ the wage, $\mathrm{P}$ the price index, GDP the gross domestic product, MA the estimated goods market access, SA the estimated goods supplier access, HKMA the estimated human capital market access, HKSA the estimated human capital supplier access, $U$ the unemployment rate, AC

\footnotetext{
6 An alternative specification was estimated where the unemployment and activity rates were replaced with their interaction. While the overall results are similar, there is some loss of information as it is not possible to know whether the interaction effect is due to either the unemployment or activity rate. However, as shown in Tables 7 and 8, the two variables behave differently. As an example, in the East the interaction variable is generally not significant, but the activity rate is very significant for all sectors.
} 
the percentage of active population, PR the sectoral productivity, PRMA access to productivity of markets, PRSA access to productivity of suppliers, and $\alpha$ country dummies.

The GDP, MA, SA, HK, HKMA and HKSA variables derive directly from NEG theory, as well as the PRMA and PRSA constructions. As shown in Section 2, these variables can generally be expected to influence real wages positively. In the estimation we distinguish the own effects (GDP, HK, PR) from the purely external effects (MA, SA, HKMA, HKSA, PRMA, PRSA). The own productivity is expected to increase wages. The productivity of the neighbours should increase wages if it complements the own productivity, but decrease them if it acts as a substitute. The remaining variables control for countries' idiosyncrasies. In particular, the country dummies are expected to capture the country-specific institutional arrangements that influence the labour market outcomes and the macroeconomic policies that determine the price levels. The dummies for each country group are estimated with reference to the country with highest real wages in that group. Thus a negative sign would indicate that there are country-specific characteristics driving real wages down, e.g., labour market rigidities and/or an inflationary macroeconomic policy with respect to the leading country. In our sample, the countries with highest real wages are Denmark in EU-North, Spain in EU-South and the Czech Republic in EU-East. 7 Unemployment and the active share of population should drive wages down by providing firms with an available pool of workers that can replace those currently employed. In what follows we compare these theoretical conjectures with the actual estimation results.

\section{Estimation Results}

We consider the EU is composed of three country groups - EU-North (N), EU-South (S) and EUEast $(E)$ - that differ in the skill endowment as well as both spatial and non-spatial trade costs. In this framework, $\mathrm{N}$ is a hub and has a higher skill endowment, this is, more skilled workers per capita, than the two peripheries $S$ and E. Sectors also differ in their characteristics, namely economies of scale and skill-intensity. We have these differences into account when estimating equation (7) Thus we regress the real wages of the three country groups for four groups of sectors distinguished by degree of economies of scale as in Pratten (1988) and skill-intensity as in Baldwin et al. (2000). These four groups are as follows: Chemicals, Machinery and Transport Equipment are high scale economies and high skill-intensive, Metals are high scale economies and low skill-

\footnotetext{
7 As explained in Section 2, the Eastern sectoral productivity data was available only for the Czech Republic, Hungary and Poland and thus only these countries were included in the regression sample. This however does not change the overall results as these three countries dominate the group of ten in terms of size and wealth. As can be seen in Section 2, the Czech Republic remains the country with highest real wages even when all Eastern countries are included. Alternative regressions (not reported) were run with all the ten countries but removing the productivity variables. The overall results are very similar to those reported in the paper.
} 
intensive, Leather \& Footwear, Minerals and Textiles \& Clothing are low scale economies and low skill-intensive, and Wood Products are low scale economies and high skill-intensive. A full description of the data sources is provided in Appendix B.

Estimation is carried out through the Prais-Winsten regression with correlated Panel Corrected Standard Errors (PCSEs), which assumes that the disturbances are heteroskedastic (each country has its own variance) and contemporaneously correlated across countries (each pair of countries has their own covariance). The full estimation results are provided in Appendix $C$. It should be noted that the results must be interpreted with caution as the initial number of observations was not very large and there was a number of missing values. This initial data was interpolated and extrapolated to increase the number of observations, which as reported in Appendix $C$ is still not more than 100 , though it is not less than 26

The country dummies indicate country-specific characteristics that drive real wages below those of the leading country. These can be institutional arrangements that make labour markets more rigid or inflationary macroeconomic policies. In the North, both Belgium and the Netherlands have such country-specific factors against Denmark in all sectors, and Austria, France, Germany, Sweden and the UK exhibit those factors in the low scale, high skill sectors. In the South, both Greece and Portugal's country-specific characteristics drive real wages in high scale, high skill sectors below the Spanish level. In the case of Portugal this is also true in low scale, high skill sectors. In the East, Hungary has a disadvantage relative to the Czech Republic in high scale sectors, whereas Poland is at odds with low skill sectors. In Tables 1-11 we analyse in more detail a summary of the main effects and respective $p$-values for the different country groups and sectors considered. 9

\begin{tabular}{|c|c|c|c|c|c|}
\hline \multirow{5}{*}{$\begin{array}{l}\text { The first group of variables } \\
\text { relates to NEG theory and } \\
\text { measures a country's own size } \\
\text { (Table 1) and that of its } \\
\text { neighbours (Tables } 2 \text { and } 3 \text { ). }\end{array}$} & \multicolumn{5}{|c|}{ Table 1: Home market } \\
\hline & & $\begin{array}{c}\text { High scale } \\
\text { economies and } \\
\text { high skill-intensity }\end{array}$ & $\begin{array}{c}\text { High scale } \\
\text { economies and } \\
\text { low skill-intensity } \\
\end{array}$ & $\begin{array}{c}\text { Low scale } \\
\text { economies and } \\
\text { high skill-intensity }\end{array}$ & $\begin{array}{c}\text { Low scale } \\
\text { economies and } \\
\text { low skill-intensity }\end{array}$ \\
\hline & $V$ & 0.595 & 0.131 & $1.229^{* \star *}$ & 0.030 \\
\hline & $S$ & $-5.997^{* * *}$ & -0.062 & $-2.908^{\star *}$ & 6.023 \\
\hline & $E$ & -0.080 & 0.282 & $1.099^{\star \star *}$ & 0.288 \\
\hline
\end{tabular}

According to theory, if the home market and the price index effects prevail, real wages will increase in the larger markets. An example is the low scale, high skill sectors in the North and East. Here there seems to be a skill effect, with more differentiated products allowing for more market power, thus increasing prices and wages. But if the competition effect in the goods and labour markets is more important, real wages

\footnotetext{
8 The scatter plots of real and interpolated data (available upon request) show that the overall trends are not substantially altered. In addition, whenever the original number of observations allowed it, we ran real data regressions. The results were very similar to the interpolated data counterparts.

9 The coefficients and p-values shown are the average of models 1 and 2 in Appendix A.
} 
will increase in the smaller markets. This happens in high skill sectors in the South. As we have shown in Section 2, Southern wages have not increased according to size, as Portuguese wages increased more than Spanish or Greek ones. The lack of significance in low skill sectors shows that the sample countries are mostly wage takers, as international competitiveness in these sectors is maintained mostly through low wages.

There are two variables measuring the importance of the size of the neighbours: market access (Table 2) and supplier access (Table 3). Good market access very substantially raises

\begin{tabular}{|c|c|c|c|c|}
\hline \multicolumn{7}{|c|}{ Table 2: Market access } \\
\hline & $\begin{array}{c}\text { High scale } \\
\text { economies and } \\
\text { high skill-intensity }\end{array}$ & $\begin{array}{c}\text { High scale } \\
\text { economies and } \\
\text { low skill-intensity }\end{array}$ & $\begin{array}{c}\text { Low scale } \\
\text { economies and } \\
\text { high skill-intensity }\end{array}$ & $\begin{array}{c}\text { Low scale } \\
\text { economies and } \\
\text { low skill-intensity }\end{array}$ \\
\hline N & 0.895 & -2.004 & 0.272 & $-0.240^{* * *}$ \\
\hline S & $6.615^{* \star *}$ & -3.320 & -2.644 & -5.242 \\
\hline E & 1.313 & $6.281^{*}$ & $-0.431^{*}$ & 1.949 \\
\hline
\end{tabular}
Southern wages in high scale, high skill sectors, and Eastern wages in high scale, low skill sectors. The competition effect in goods markets prevails in the East's low scale, high skill sectors and the North's low scale, low skill sectors. When significant, the signs are positive in high scale sectors and negative in low scale sectors. This is mostly a scale effect coming out of the interplay between advantages from concentration and from locating close to markets and suppliers. In high scale sectors, the gain from concentrating exceeds the loss from being further away from markets and suppliers. An increase in market access always decreases production costs and allows the firm to increase wages, at the same time lowering the price index. The result is an increase in real wages. In low scale sectors, concentration gains do not compensate the increase in transport costs. Thus better market access may in fact increase the overall firm's costs by increasing concentration and as a result real wages decrease.

The access to suppliers, when significant, always increases real wages. Examples are high skill sectors in the peripheries and high scale, low skill in the North. Better access to suppliers means

\begin{tabular}{|c|c|c|c|c|}
\hline \multicolumn{7}{|c|}{ Table 3: Supplier access } \\
\hline & $\begin{array}{c}\text { High scale } \\
\text { economies and } \\
\text { high skill-intensity }\end{array}$ & $\begin{array}{c}\text { High scale } \\
\text { economies and } \\
\text { low skill-intensity }\end{array}$ & $\begin{array}{c}\text { Low scale } \\
\text { economies and } \\
\text { high skill-intensity }\end{array}$ & $\begin{array}{c}\text { Low scale } \\
\text { economies and } \\
\text { low skill-intensity }\end{array}$ \\
\hline N & -0.034 & $3.184^{*}$ & -0.393 & 1.658 \\
\hline S & $0.914^{\star}$ & 3.146 & $6.406^{* * *}$ & -0.027 \\
\hline E & 1.828 & -4.113 & $5.632^{* * *}$ & 0.185 \\
\hline
\end{tabular}
lower transport costs and thus lower cost of inputs. This decreases the price index and allows real wages to increase. The marginal effects are higher for low scale sectors as these are more affected by transport costs. Generally, in Tables 1 to 3, the marginal effects on real wages are higher for South and East than for North. This confirms the latter's position as a hub: as it already has a locational advantage, any improvements would bring reduced marginal gains. In addition, a multinational firms effect is apparent in the Southern high scale, high skill sectors as both access to suppliers and markets influence real wages positively, but the size of the home market influences real wages negatively. Thus the real wages paid in these sectors have grown in the South not due 
to the home market but due to the action of external markets and/or firms. These sectors are dependent on both external suppliers and markets.

We now turn to factor markets, more exactly the market for skilled labour: own human capital endowments (Table 4), access to human capital markets (Table 5) and access to human capital

\begin{tabular}{|c|c|c|c|c|}
\hline \multicolumn{5}{|c|}{ Table 4: Endowments } \\
\hline & $\begin{array}{c}\text { High scale } \\
\text { economies and } \\
\text { high skill-intensity }\end{array}$ & $\begin{array}{c}\text { High scale } \\
\text { economies and } \\
\text { low skill-intensity }\end{array}$ & $\begin{array}{c}\text { Low scale } \\
\text { economies and } \\
\text { high skill-intensity }\end{array}$ & $\begin{array}{c}\text { Low scale } \\
\text { economies and } \\
\text { low skill-intensity }\end{array}$ \\
\hline $\mathrm{N}$ & 0.014 & -0.111 & $-0.172^{\star}$ & 0.072 \\
\hline $\mathrm{S}$ & -0.144 & -0.317 & 0.198 & -0.439 \\
\hline $\mathrm{E}$ & $1.526^{* \star *}$ & $0.779^{\star * *}$ & -0.096 & 0.663 \\
\hline
\end{tabular}
suppliers (Table 6). In the East, the effect of own endowments on wages is always positive when significant, meaning that demand effects overcome supply effects. In high scale sectors, due to large FDI inflows, human capital is in high demand relatively to supply, driving up wages. Moreover, as Eastern labour markets were liberalised, wages responded more freely to market forces. In Western Europe, the responsiveness of wages to endowments has already achieved a threshold and the only significant reaction is actually negative (North's low scale, high skill).

The access to markets abundant in human capital decreases real wages when significant. This happens in low scale, high skill sectors for the North and East. There is no wage premium

\begin{tabular}{|c|c|c|c|c|}
\hline \multicolumn{5}{|c|}{ Table 5: Human capital market access } \\
\hline & $\begin{array}{c}\text { High scale } \\
\text { economies and } \\
\text { high skill-intensity }\end{array}$ & $\begin{array}{c}\text { High scale } \\
\text { economies and } \\
\text { low skill-intensity }\end{array}$ & $\begin{array}{c}\text { Low scale } \\
\text { economies and } \\
\text { high skill-intensity }\end{array}$ & $\begin{array}{c}\text { Low scale } \\
\text { economies and } \\
\text { low skill-intensity }\end{array}$ \\
\hline N & 0.225 & 0.100 & $-0.456^{\star \star \star}$ & -0.058 \\
\hline S & 0.453 & -0.073 & -0.473 & 0.738 \\
\hline E & 0.072 & -2.672 & $-2.102^{\star \star \star}$ & 1.593 \\
\hline
\end{tabular}
associated with producing for sophisticated markets as these are also more competitive and consumers are more demanding. They would be willing to accept higher prices only for products originating from distant suppliers. As market access improves, prices are driven down and so are wages.

The access to human capital suppliers adds to the own endowments and it could either complement or substitute it. Foreign human capital is a complement to own human

\begin{tabular}{|c|c|c|c|c|}
\hline \multicolumn{5}{|c|}{ Table 6: Human capital suppliers access } \\
\hline & $\begin{array}{c}\text { High scale } \\
\text { economies and } \\
\text { high skill-intensity }\end{array}$ & $\begin{array}{c}\text { High scale } \\
\text { economies and } \\
\text { low skill-intensity }\end{array}$ & $\begin{array}{c}\text { Low scale } \\
\text { economies and } \\
\text { high skill-intensity }\end{array}$ & $\begin{array}{c}\text { Low scale } \\
\text { economies and } \\
\text { low skill-intensity }\end{array}$ \\
\hline N & 0.066 & 0.101 & $0.457^{* * *}$ & 0.002 \\
\hline S & -0.019 & 0.949 & 0.640 & -0.941 \\
\hline E & $-1.189^{\star * *}$ & 0.682 & -0.384 & $-3.750^{\star *}$ \\
\hline
\end{tabular}
capital in the North in low scale, high skill sectors. These require a relatively high proportion of skilled labour and, being low scale, are relatively localised. In the East, foreign human capital substitutes for local human capital in high scale, high skill and low scale, low skill sectors. These have seen foreign networks grow, either through FDI or outsourcing. However, local employment is 
made mostly of unskilled workers as multinationals resort to skilled workers from their countries of origin.

We use three control variables

that account for different country/sector characteristics.

The first is labour productivity, defined as the sectoral production per worker (Table 7).

\begin{tabular}{|c|c|c|c|c|}
\hline \multicolumn{5}{|c|}{ Table 7: Productivity } \\
\hline & $\begin{array}{c}\text { High scale } \\
\text { economies and } \\
\text { high skill-intensity }\end{array}$ & $\begin{array}{c}\text { High scale } \\
\text { economies and } \\
\text { low skill-intensity }\end{array}$ & $\begin{array}{c}\text { Low scale } \\
\text { economies and } \\
\text { high skill-intensity }\end{array}$ & $\begin{array}{c}\text { Low scale } \\
\text { economies and } \\
\text { low skill-intensity }\end{array}$ \\
\hline N & $-0.036^{* * *}$ & $-0.106^{* *}$ & $-0.013^{*}$ & 0.018 \\
\hline S & 0.008 & -0.024 & 0.007 & 0.002 \\
\hline E & 0.060 & 0.032 & $0.116^{* * *}$ & 0.106 \\
\hline
\end{tabular}

In the North productivity tends to have a negative effect on real wages in all sectors except low scale, low skill. Several explanations for this result can be put forward. One relates to technology improvements that allow the introduction of more capital-intensive techniques. The increase in labour productivity may be due to less employment rather than more production. Thus the demand for labour decreases and real wages decrease as well. Disney et al. (2003) study the relationship between restructuring and productivity in the UK. They find a positive impact of both internal and external restructuring on productivity of UK firms, partly because of the introduction of more capitalintensive techniques. This reduces labour demand and, holding labour supply constant, it drives wages down. A second reason has to do with the introduction of capital also inducing substitution of unskilled for skilled workers. Thus, even if wages respond to productivity, as unskilled wages are lower than skilled wages, on average real wages may decrease. Finally, there is a competition effect from more efficient firms in the sector that compresses real wages downwards. In the South real wages are unresponsive to productivity, as shown in Section 2. There it was also shown that Hungarian real wages decrease with productivity, whereas Czech and Polish real wages increase. This behaviour renders the coefficients in Table 7 insignificant for the East, though they remain positive. The only exception is low scale, high skill sectors, where productivity significantly increases real wages. This can be explained through a positive spillover argument according to which inefficient firms are forced to become more productive thus being able to pay higher wages.

Similarly to GDP and human capital, we can think of the influence of the neighbours' productivity on a country's real wages. These are affected by the productivity of markets (Table 8 )

\begin{tabular}{|c|c|c|c|c|}
\hline \multicolumn{5}{|c|}{ Table 8: Productivity market access } \\
\hline & $\begin{array}{c}\text { High scale } \\
\text { economies and } \\
\text { high skill-intensity }\end{array}$ & $\begin{array}{c}\text { High scale } \\
\text { economies and } \\
\text { low skill-intensity }\end{array}$ & $\begin{array}{c}\text { Low scale } \\
\text { economies and } \\
\text { high skill-intensity }\end{array}$ & $\begin{array}{c}\text { Low scale } \\
\text { economies and } \\
\text { low skill-intensity }\end{array}$ \\
\hline N & -0.222 & 0.012 & 0.022 & $-0.420^{\star *}$ \\
\hline S & 0.080 & 0.291 & $-0.115^{\star * \star}$ & 0.009 \\
\hline E & $-0.153^{\star \star *}$ & 0.128 & $-0.023^{\star * *}$ & 0.183 \\
\hline
\end{tabular}
and of suppliers (Table 9). The effect of access to productive markets on real wages, when significant, is always negative. This is because a country that has very productive neighbours has to either increase its own productivity or to keep its wages low to remain competitive. The latter solution is easier to achieve in the short run. Examples are high scale, high skill sectors in the East, 
low scale, high skill sectors in the peripheries and low scale, low skill sectors in the North. In addition, the comment made before about the downskilling due to more capital-intensive techniques would also apply here.

The productivity of suppliers has a significantly negative impact on real wages only in the East in low scale, high skill sectors. This sector (Wood Products) is partially dependent on natural

\begin{tabular}{|c|c|c|c|c|}
\hline \multicolumn{5}{|c|}{ Table 9: Productivity supplier access } \\
\hline & $\begin{array}{c}\text { High scale } \\
\text { economies and } \\
\text { high skill-intensity }\end{array}$ & $\begin{array}{c}\text { High scale } \\
\text { economies and } \\
\text { low skill-intensity }\end{array}$ & $\begin{array}{c}\text { Low scale } \\
\text { economies and } \\
\text { high skill-intensity }\end{array}$ & $\begin{array}{c}\text { Low scale } \\
\text { economies and } \\
\text { low skill-intensity }\end{array}$ \\
\hline N & 0.162 & -0.040 & 0.010 & 0.325 \\
\hline S & -0.206 & -0.297 & 0.072 & -0.102 \\
\hline E & 0.046 & -0.092 & $-0.224^{* * *}$ & -0.307 \\
\hline
\end{tabular}
resources and, as the more skill-intensive stages are not related to the supply of inputs, a negative effect of closer productive suppliers would be expected.

The second control variable is the country's general unemployment rate (Table 10), that indicates how easily current workers may be replaced and how easy it is to draw extra

\begin{tabular}{|c|c|c|c|c|}
\hline \multicolumn{5}{|c|}{ Table 10: Unemployment } \\
\hline & $\begin{array}{c}\text { High scale } \\
\text { economies and } \\
\text { high skill-intensity }\end{array}$ & $\begin{array}{c}\text { High scale } \\
\text { economies and } \\
\text { low skill-intensity }\end{array}$ & $\begin{array}{c}\text { Low scale } \\
\text { economies and } \\
\text { high skill-intensity }\end{array}$ & $\begin{array}{c}\text { Low scale } \\
\text { economies and } \\
\text { low skill-intensity }\end{array}$ \\
\hline N & 0.016 & 0.005 & $0.081^{\star * \star}$ & 0.008 \\
\hline S & $-0.459^{* * *}$ & $-0.192^{\star *}$ & $-0.226^{* *}$ & 0.240 \\
\hline E & 0.031 & $0.152^{* *}$ & $0.287^{* \star *}$ & $0.192^{\star \star *}$ \\
\hline
\end{tabular}
workers. Both tend to drive down wages in the South. There is however a perverse effect in the East (except high scale, high skill sectors), where unemployment drives wages upwards. The positive effect of unemployment on wages is the product of industrial restructuring. It is especially noticeable in the East during the transition period, when both unemployment and wages increased as market forces drove out inefficient workers and firms. In high scale, high skill sectors the FDI flows prevented a significant link between unemployment and wages. The North's low scale, high skill sectors also show a positive link between unemployment and wages.

The third control variable is the activity rate, defined as the share of active population in the country's total population (Table 11). This is mainly dependent on demographic and social factors

\begin{tabular}{|c|c|c|c|c|}
\hline \multicolumn{7}{|c|}{ Table 11: Activity rate } \\
\hline & $\begin{array}{c}\text { High scale } \\
\text { economies and } \\
\text { high skill-intensity }\end{array}$ & $\begin{array}{c}\text { High scale } \\
\text { economies and } \\
\text { low skill-intensity }\end{array}$ & $\begin{array}{c}\text { Low scale } \\
\text { economies and } \\
\text { high skill-intensity }\end{array}$ & $\begin{array}{c}\text { Low scale } \\
\text { economies and } \\
\text { low skill-intensity }\end{array}$ \\
\hline N & -0.387 & $-0.529^{*}$ & 0.097 & 0.206 \\
\hline S & -1.420 & -0.610 & 0.016 & 4.192 \\
\hline E & $4.506^{* * *}$ & $2.251^{* *}$ & $4.600^{* * *}$ & $2.500^{\star * *}$ \\
\hline
\end{tabular}
that however differ across countries. Some examples are the extent of the ageing phenomenon and the participation rate of women. Similarly to the unemployment rate, the activity rate provides a measure of the ease of labour force replacement and/or augmentation. The smaller the pool of inactive people the less options there are for employers, who are forced to pay higher wages. Thus the activity rate should have a positive effect on wages. In fact, for the East the effect is always 
positive and even more so in the sectors that require relatively more skilled labour. This is because skilled workers are scarcer and thus competition for workers is fiercer in these sectors, driving wages upwards. However, for the North the effect is negative in high scale, low skill sectors. This behaviour can be better understood if we think about the competition that a greater activity rate creates in the labour market, thus driving wages down.

Previous studies estimated a wage equation where wages are a function of market and supplier access and also of access to a pool of skilled workers. In turn these variables are distance-weighted averages of incomes and human capital using distance coefficients taken from a gravity model. Examples at an aggregate level are Hanson $(1997,1998)$ on NAFTA and Redding and Venables (2001) and Venables (2001) in a worldwide context. Like ours, these studies conclude that wages increase with proximity to markets and suppliers. Hanson $(1997,1998)$ finds that in Mexico nominal wages decrease with the distance from industrial centres but were not influenced by NAFTA trade liberalisation. However the movement of people was not considered in the study and it refers to observable data rather than projecting into the future. Venables (2001) finds two European wage gradients, one from the EU core to Greece, Portugal and Spain, and another from Western to Eastern Europe. These are however aggregate wages and do not distinguish sectoral effects. Using regional data for respectively Canada and the UK, Hunt and Mueller (2002) and Monastiriotis (2002) conclude that regions with more human capital tend to have higher average wages.

Our results are not directly comparable with these previous studies. The scope in terms of countries and sectors differs as we use an exclusively European sample and disaggregate industrial sectors. By doing this, we additionally find that the effects on specific sectors can be much higher than suggested by aggregate data, and have shown how different the results are across sectors.

\section{Conclusions}

In this paper we have estimated a sectoral wage equation for three regional blocs of the enlarged EU that we defined as North, South and East. We are now able to characterise the factors that influenced changes in real wages during the 1990s in our sample countries and sectors. Though the overall relationship either between size, endowments or productivity and real wages is positive, these react more to size, less to endowments and even less to productivity. These reactions, when significant, also differ among countries and sectors when we jointly regress real wages. Sectorally, the most consistent result is that in all countries market access increases wages of high scale sectors but decreases wages of low scale sectors. This is because the former gain more in scale economies than they lose in transport costs, whereas the opposite is true for the latter. 
The model works particularly well for the East, with own size, endowments, productivity, unemployment and activity rates having a positive effect on real wages. The Eastern economies particularly benefit from opening to foreign markets, especially in high scale sectors. At the same time, they are subject to competition effects from foreign skills and productivity. The model also shows that in the North own size and unemployment rate increase real wages, but these show threshold effects in own human capital, productivity and activity rates as high levels have already been achieved. As Northern countries are more productive than their EU neighbours, their real wages are not affected by other's productivity. However, real wages increase with the suppliers' size and skill but decrease with the markets' size and skill. Thus suppliers complement internal production, which competes in external markets. In the South, real wages are negatively affected by own size and unemployment as real wages increased the most in Portugal, the country with lowest levels of these variables. The size of markets and suppliers alone increases real wages, whereas the Southern countries are subject to a competition effect in productive markets.

Our results come as a support of recent developments in the EU's Agenda 2000, which has been a first step in the right direction by emphasising different roles for the EU's Regional Policy. The latter should in fact be a mix of policies, focussing on both income and education/skills, together with infrastructure development. This last aspect has successfully benefited Southern Europe and the same would be expected in Eastern Europe. The support of Regional Policy may be particularly important to compensate the market forces that tend to increase real wages where they are already higher. In particular, even if the real wages in the EU as a whole increase, we should bear in mind the possibility of an uneven change across different regions of the EU. In addition, the EU's Regional Policy should be increasingly sector-specific as the behaviour of sectoral wages differs from the aggregate.

What has been said in the European context may be extrapolated at the worldwide level. Developing countries that suffer from poor market access, low human capital endowments and low productivity are failing to converge. Institutions such as the World Bank would have a role, adopting a balanced mix of policies, fostering both income and education/skill levels, together with infrastructure improvement. The policy mix should be less general and pay attention to the particular characteristics of countries and sectors that it seeks to influence. 


\section{References}

Baldwin, R., Forslid, R., Haaland, J. and Midelfart-Knarvik, K. (2000), Eu Integration and Outsiders: A Simulation Study of Industrial Location, Norwegian School of Economics and Business Administration Discussion Paper, 02/2000.

Commission, E. (2001), The Free Movement of Workers in the Context of Enlargement, DG-V, Brussels.

Disney, R., Haskel, J. and Heden, Y. (2003), Restructuring and Productivity Growth in Uk Manufacturing, Economic Journal, 113, 666-94.

Hanson, G. (1997), Increasing Returns, Trade and the Regional Structure of Wages, Economic Journal, 107, 113-133.

Hanson, G. (1998), Market Potential, Increasing Returns and Geographic Concentration, NBER WP 6429.

Harris, C. (1954), The Market as a Factor in the Localisation of Industry in the United States, Annals of the Association of American Geographers, 64, 315-48.

Hunt, G. and Mueller, R. (2002), A Methodology for Estimating Returns to Skills for Canadian Provinces and Us States, Journal of Regional Science, 42, 127-43.

Marques, H. and Metcalf, H. (2003), A Gravity Study of the Sectoral Trade Impact of Skilled Migration in an Enlarged EU, Newcastle University Economics Working Paper 2003/01.

Monastiriotis, V. (2002), Human Capital and Wages: Evidence for External Effects from the UK Regions, Applied Economics Letters, 9, 843-46.

Overman, H., Redding, S. and Venables, A. (2001), The Economic Geography of Trade, Production and Income: A Survey of Empirics, CEPR DP 2978.

Pratten, C. (1988), A Survey of Economies of Scale, In Research on the Cost of Non-Europe, Vol. 2 (Ed, CEC) CEC, Luxembourg.

Redding, S. and Venables, A. (2001), Economic Geography and International Inequality, CEP DP 495.

Venables, A. (2001), Geography and International Inequalities: The Impact of New Technologies, CEP DP 507. 


\section{Appendix A}

\section{Distance Coefficients (as estimated in Marques and Metcalf 2003)}

\begin{tabular}{|c|l|l|l|l|l|l|l|}
\hline \multirow{2}{*}{$\begin{array}{c}\text { Panel Corrected } \\
\text { Standard Errors }\end{array}$} & \multicolumn{2}{|c|}{ N-E } & \multicolumn{2}{c|}{ N-S } & \multicolumn{2}{c|}{ S-E } \\
\cline { 2 - 8 } $\begin{array}{c}\text { Chemicals } \\
\text { Che }\end{array}$ & Exports & -1.030 & -1.141 & -2.072 & -1.224 & -1.574 & -3.587 \\
\cline { 2 - 8 } & Imports & -1.426 & -1.398 & -0.331 & -0.050 & -2.070 & -1.455 \\
\hline \multirow{2}{*}{ Leather } & Exports & -2.515 & -2.570 & -3.045 & -3.211 & -1.173 & -0.770 \\
\cline { 2 - 8 } & Imports & -0.984 & -1.442 & -2.800 & -2.984 & -0.325 & 0.371 \\
\hline \multirow{2}{*}{ Machinery } & Exports & -1.418 & -1.754 & -0.543 & -0.595 & -2.021 & -1.732 \\
\cline { 2 - 8 } & Imports & -0.840 & -0.766 & -0.319 & 0.236 & -4.608 & -2.172 \\
\hline \multirow{2}{*}{ Metals } & Exports & -1.957 & -2.136 & -0.435 & 0.169 & -1.133 & -2.050 \\
\cline { 2 - 8 } & Imports & -1.776 & -2.328 & -0.877 & -0.454 & -3.913 & -3.101 \\
\hline \multirow{2}{*}{ Minerals } & Exports & -2.201 & -2.103 & -1.972 & -2.138 & -0.783 & -2.627 \\
\cline { 2 - 8 } & Imports & -1.742 & -2.100 & -0.471 & -0.797 & -4.609 & -4.235 \\
\hline \multirow{2}{*}{ Textiles } & Exports & -2.159 & -2.223 & -2.520 & -2.432 & -0.569 & -0.962 \\
\cline { 2 - 8 } & Imports & -1.295 & -1.501 & -0.644 & -0.339 & -1.666 & -1.554 \\
\hline \multirow{2}{*}{$\begin{array}{c}\text { Transport } \\
\text { Equipment }\end{array}$} & Exports & -2.378 & -2.528 & -1.353 & -1.085 & -3.858 & -1.799 \\
\cline { 2 - 8 } & Imports & -2.082 & -3.051 & -1.147 & -1.135 & -0.350 & -1.558 \\
\hline \multirow{2}{*}{ Wood } & Exports & -2.270 & -2.361 & -0.325 & -0.285 & -2.110 & -2.627 \\
\cline { 2 - 7 } & Imports & -0.822 & -0.984 & -2.119 & -1.111 & -1.543 & -2.784 \\
\hline
\end{tabular}

NOTE: Model 1 is defined as

TRADE $_{i j t}^{k}=$ POP $_{i t} \beta_{1}+$ POP $_{j t} \beta_{2}+$ GDPPC $_{i t} \beta_{3}+$ GDPPC $_{j t} \beta_{4}+\mathrm{HKPC}_{i t} \beta_{5}+\mathrm{HKPC}_{\mathrm{jt}} \beta_{6}+\mathrm{DIST}_{\mathrm{ij}} \beta_{7}+$ + BORDER $_{\mathrm{ij}} \beta_{8}+\mathrm{EA}_{\mathrm{ijt}} \beta_{9}+\mathrm{EURO}_{\mathrm{ijt}} \beta_{10}+\mathrm{u}_{\mathrm{ijt}}^{\mathrm{k}}$

and Model 2 is defined as

TRADE $_{i j t}^{k}=$ POP $_{i t} \beta_{1}+$ POP $_{i t} \beta_{2}+$ ECDIST $_{i j t} \beta_{3}+$ HKDIST $_{t} \beta_{4}+$ DIST $_{i j} \beta_{5}+$ BORDER $_{i j} \beta_{6}+\mathrm{EA}_{i j t} \beta_{7}+$ EURO $_{i j t} \beta_{8}+u_{i j t}^{k}$.

where the dependent variable is either exports or imports between countries I and $\mathrm{j}$ for sector $\mathrm{k}$, year $\mathrm{t}$.

The coefficients reported above correspond to $\beta_{7}$ in Model 1 and to $\beta_{5}$ in Model 2. 


\section{Appendix B}

\section{Data Sources}

Data is taken for the transition period (1990-99), for the following industrial aggregates:

- ISIC Rev. 2: chemicals (35), leather products $(323,324)$, machinery $(382,383)$, metals (37, $381)$, minerals $(36)$, textiles and clothing $(321,322)$, transport equipment $(384)$, and wood products (33);

- ISIC Rev. 3: chemicals (24), leather products (19), machinery (29, 30, 31), metals (27, 28), minerals $(26)$, textiles and clothing $(17,18)$, transport equipment $(34,35)$, and wood products $(20,36)$.

Data on wages, prices, employment, unemployment and labour force is provided by the International Labour Organisation's Yearbook of Labour Statistics. Industrial production data was taken from OECD's Industrial Structure Statistics.

The remaining variables are composites that use the coefficients provided in Appendix A, together with distance, GDP and human capital data. Distance data was taken from the CEPII website www.cepii.fr and it is measured in km between the sample countries' economic centres. These correspond to the capital city except for Germany (Hamburg is the city used). GDP data was taken from the IMF's International Financial Statistics. Human capital is proxied by a schooling variable given by the number of people with tertiary education studies. This number was obtained from the Barro-Lee dataset for 1990 and then added of the yearly number of enrolments. The enrolment data was taken from the OECD Education Statistics and UNESCO Statistics of Educational Attainment and Literacy. 


\section{Appendix C}

\section{Regression Results}

\begin{tabular}{|c|c|c|c|c|c|c|}
\hline \multirow{2}{*}{ Chemicals } & \multicolumn{2}{|c|}{ North } & \multicolumn{2}{|c|}{ South } & \multicolumn{2}{|c|}{ East } \\
\hline & Model 1 & Model 2 & Model 1 & Model 2 & Model 1 & Model 2 \\
\hline gdp & $\begin{array}{c}0.184 \\
(0.206)\end{array}$ & $\begin{array}{c}0.099 \\
(0.208)\end{array}$ & $\begin{array}{c}-7.719^{\star \star \star} \\
(1.042)\end{array}$ & $\begin{array}{c}-9.121^{\star * \star} \\
(1.287)\end{array}$ & $\begin{array}{c}-0.062 \\
(0.081)\end{array}$ & $\begin{array}{c}-0.044 \\
(0.083)\end{array}$ \\
\hline ma & $\begin{array}{c}3.024^{\star \star *} \\
(1.108)\end{array}$ & $\begin{array}{l}2.739^{\star *} \\
(1.155)\end{array}$ & $\begin{array}{c}3.166^{\star * *} \\
(0.858)\end{array}$ & $\begin{array}{l}6.696^{\star *} \\
(3.108)\end{array}$ & $\begin{array}{c}5.132^{\star * \star} \\
(1.042)\end{array}$ & $\begin{array}{c}6.371 \\
(1.496)\end{array}$ \\
\hline sa & $\begin{array}{c}-1.635^{\star * *} \\
(0.670)\end{array}$ & $\begin{array}{l}-1.189^{*} \\
(0.650)\end{array}$ & $\begin{array}{c}5.407^{\star \star \star} \\
(0.816)\end{array}$ & $\begin{array}{c}4.159 \\
(4.049)\end{array}$ & $\begin{array}{c}0.494 \\
(0.598)\end{array}$ & $\begin{array}{l}-0.741 \\
(0.850)\end{array}$ \\
\hline hk & $\begin{array}{c}0.067 \\
(0.136)\end{array}$ & $\begin{array}{c}0.061 \\
(0.162)\end{array}$ & $\begin{array}{c}0.828^{\star * *} \\
(0.078)\end{array}$ & $\begin{array}{c}0.791^{\star * *} \\
(0.131)\end{array}$ & $\begin{array}{c}0.995^{\star \star \star} \\
(0.257)\end{array}$ & $\begin{array}{c}1.029 \\
(0.301)\end{array}$ \\
\hline hkma & $\begin{array}{c}0.854^{* * *} \\
(0.328) \\
\end{array}$ & $\begin{array}{l}0.754^{* *} \\
(0.392)\end{array}$ & $\begin{array}{l}0.320^{\star \star} \\
(0.132) \\
\end{array}$ & $\begin{array}{c}0.809 \\
(0.672) \\
\end{array}$ & $\begin{array}{c}1.731^{* * *} \\
(0.430)\end{array}$ & $\begin{array}{l}2.322^{*} \\
(0.655) \\
\end{array}$ \\
\hline hksa & $\begin{array}{c}-0.122 \\
(0.154) \\
\end{array}$ & $\begin{array}{c}-0.099 \\
(0.126) \\
\end{array}$ & $\begin{array}{c}-0.783^{\star \star \star} \\
(0.222)\end{array}$ & $\begin{array}{c}-0.401 \\
(0.519) \\
\end{array}$ & $\begin{array}{c}-3.197^{\star * *} \\
(0.740)\end{array}$ & $\begin{array}{l}-3.870^{*} \\
(0.964) \\
\end{array}$ \\
\hline $\mathrm{pr}$ & $\begin{array}{c}-0.058^{* *} \\
(0.027)\end{array}$ & $\begin{array}{c}-0.060^{\star *} \\
(0.030)\end{array}$ & $\begin{array}{c}-0.095^{\star * *} \\
(0.024)\end{array}$ & $\begin{array}{c}-0.056^{\star *} \\
(0.028)\end{array}$ & $\begin{array}{l}0.046^{\star *} \\
(0.020)\end{array}$ & $\begin{array}{c}0.049^{\star * *} \\
(0.019)\end{array}$ \\
\hline prma & $\begin{array}{c}-0.066^{\star *} \\
(0.034)\end{array}$ & $\begin{array}{c}-0.071^{* *} \\
(0.036)\end{array}$ & $\begin{array}{c}0.078^{\star * *} \\
(0.011)\end{array}$ & $\begin{array}{c}0.074 \\
(0.053) \\
\end{array}$ & $\begin{array}{c}-0.148^{\star * *} \\
(0.053)\end{array}$ & $\begin{array}{c}-0.168^{\star * *} \\
(0.068)\end{array}$ \\
\hline prsa & $\begin{array}{l}-0.028 \\
(0.021) \\
\end{array}$ & $\begin{array}{l}-0.015 \\
(0.014) \\
\end{array}$ & $\begin{array}{c}-0.240^{* * *} \\
(0.045) \\
\end{array}$ & $\begin{array}{c}-0.413^{\star * *} \\
(0.126) \\
\end{array}$ & $\begin{array}{c}-0.058 \\
(0.045) \\
\end{array}$ & $\begin{array}{c}-0.043^{\star * *} \\
(0.066)\end{array}$ \\
\hline u & $\begin{array}{c}0.012 \\
(0.032)\end{array}$ & $\begin{array}{c}0.005 \\
(0.034) \\
\end{array}$ & $\begin{array}{c}-0.662^{\star * \star} \\
(0.045)\end{array}$ & $\begin{array}{c}-0.628^{\star \star *} \\
(0.115)\end{array}$ & $\begin{array}{c}0.004 \\
(0.030)\end{array}$ & $\begin{array}{c}0.016 \\
(0.030)\end{array}$ \\
\hline active & $\begin{array}{l}-0.386 \\
(0.257) \\
\end{array}$ & $\begin{array}{l}-0.393 \\
(0.278) \\
\end{array}$ & $\begin{array}{l}1.346^{* \star *} \\
(0.361)\end{array}$ & $\begin{array}{l}1.184^{\star \star *} \\
(0.470)\end{array}$ & $\begin{array}{c}1.921^{\star \star \star} \\
(0.477)\end{array}$ & $\begin{array}{c}1.820 \\
(0.457) \\
\end{array}$ \\
\hline aus & $\begin{array}{c}0.871^{*} \\
(0.488)\end{array}$ & $\begin{array}{l}0.920^{*} \\
(0.520)\end{array}$ & & & & \\
\hline bel & $\begin{array}{c}-1.412^{\star * *} \\
(0.241)\end{array}$ & $\begin{array}{c}-1.561^{\star * *} \\
(0.328)\end{array}$ & & & & \\
\hline fin & $\begin{array}{c}2.434^{* * *} \\
(0.940)\end{array}$ & $\begin{array}{l}2.410^{* *} \\
(1.050)\end{array}$ & & & & \\
\hline fra & $\begin{array}{c}0.110 \\
(0.580) \\
\end{array}$ & $\begin{array}{l}-0.058 \\
(0.539) \\
\end{array}$ & & & & \\
\hline ger & $\begin{array}{c}0.962 \\
(0.766)\end{array}$ & $\begin{array}{c}1.099 \\
(0.785)\end{array}$ & & & & \\
\hline ire & $\begin{array}{l}1.112^{*} \\
(0.598)\end{array}$ & $\begin{array}{c}0.780 \\
(0.573)\end{array}$ & & & & \\
\hline ned & $\begin{array}{c}-0.986^{\star \star *} \\
(0.208)\end{array}$ & $\begin{array}{c}-1.058^{\star * *} \\
(0.256)\end{array}$ & & & & \\
\hline swe & $\begin{array}{l}1.573^{\star \star} \\
(0.684)\end{array}$ & $\begin{array}{l}1.632^{\star *} \\
(0.777)\end{array}$ & & & & \\
\hline uk & $\begin{array}{c}0.323 \\
(0.442)\end{array}$ & $\begin{array}{c}0.226 \\
(0.415)\end{array}$ & & & & \\
\hline gre & & & $\begin{array}{c}13.603^{\star \star \star} \\
(1.759)\end{array}$ & $\begin{array}{c}-14.127^{\star \star \star} \\
(2.214) \\
\end{array}$ & & \\
\hline por & & & $\begin{array}{c}-18.774^{\star \star \star} \\
(2.972)\end{array}$ & $\begin{array}{c}19.069^{\star * \star} \\
(2.239)\end{array}$ & & \\
\hline hun & & & & & $\begin{array}{c}2.296^{* * *} \\
(0.563)\end{array}$ & $\begin{array}{c}2.386^{* * *} \\
(0.641)\end{array}$ \\
\hline pol & & & & & $\begin{array}{c}0.377 \\
(0.660) \\
\end{array}$ & $\begin{array}{c}0.414^{*} \\
(0.756) \\
\end{array}$ \\
\hline constant & $\begin{array}{c}-37.266^{\star \star \star} \\
(12.241) \\
\end{array}$ & $\begin{array}{c}-36.110^{\star \star \star} \\
(11.146)\end{array}$ & $\begin{array}{c}-1.802 \\
(12.726) \\
\end{array}$ & $\begin{array}{r}-22.643 \\
(34.445) \\
\end{array}$ & $\begin{array}{c}-136.358^{\star \star *} \\
(20.768) \\
\end{array}$ & $\begin{array}{c}-133.999^{\star * *} \\
(22.065)\end{array}$ \\
\hline No. obs. & 99 & 99 & 30 & 30 & 28 & 28 \\
\hline $\mathrm{R}^{2}$ & 0.9965 & 0.9954 & & & 0.9966 & \\
\hline Wald $\mathrm{Chi}^{2}$ & $8920.37^{\star \star \star}$ & $10073.93^{\star \star \star}$ & $8099.68^{\star \star \star}$ & $3301.89^{* \star \star}$ & $9737.93^{* \star \star}$ & $8198.95^{\star \star \star}$ \\
\hline
\end{tabular}




\begin{tabular}{|c|c|c|c|c|c|c|}
\hline \multirow{2}{*}{$\begin{array}{c}\text { Leather \& } \\
\text { footwear }\end{array}$} & \multicolumn{2}{|c|}{ North } & \multicolumn{2}{|c|}{ South } & \multicolumn{2}{|c|}{ East } \\
\hline & Model 1 & Model 2 & Model 1 & Model 2 & Model 1 & Model 2 \\
\hline gdp & $\begin{array}{c}-0.181^{\star \star *} \\
(0.060)\end{array}$ & $\begin{array}{c}0.012 \\
(0.055) \\
\end{array}$ & $\begin{array}{l}-1.136 \\
(0.866) \\
\end{array}$ & $\begin{array}{c}0.210 \\
(0.377) \\
\end{array}$ & $\begin{array}{l}0.524^{\star *} \\
(0.241)\end{array}$ & $\begin{array}{c}0.248^{\star \star \star} \\
(0.190)\end{array}$ \\
\hline ma & $\begin{array}{c}-6.558^{\star \star \star} \\
(0.818)\end{array}$ & $\begin{array}{c}-9.076^{\star \star \star} \\
(0.729) \\
\end{array}$ & $\begin{array}{c}1.246 \\
(0.847) \\
\end{array}$ & $\begin{array}{c}-0.371 \\
(0.696)\end{array}$ & $\begin{array}{c}0.172 \\
(0.944)\end{array}$ & $\begin{array}{l}-0.690 \\
(3.369)\end{array}$ \\
\hline sa & $\begin{array}{l}7.182^{\star \star \star} \\
(0.890)\end{array}$ & $\begin{array}{c}9.573^{\star \star \star} \\
(0.736)\end{array}$ & $\begin{array}{l}-0.063 \\
(0.241)\end{array}$ & $\begin{array}{c}0.117 \\
(0.631)\end{array}$ & $\begin{array}{l}-0.101 \\
(1.004)\end{array}$ & $\begin{array}{l}1.314^{\star \star} \\
(2.783)\end{array}$ \\
\hline hk & $\begin{array}{c}0.101^{* * *} \\
(0.029)\end{array}$ & $\begin{array}{c}0.161^{\star * \star} \\
(0.038)\end{array}$ & $\begin{array}{l}0.245^{\star *} \\
(0.120)\end{array}$ & $\begin{array}{c}0.237 \\
(0.171)\end{array}$ & $\begin{array}{l}0.854^{*} \\
(0.450)\end{array}$ & $\begin{array}{l}0.934^{\star \star} \\
(0.302)\end{array}$ \\
\hline hkma & $\begin{array}{c}-0.747^{* \star *} \\
(0.197) \\
\end{array}$ & $\begin{array}{l}-0.519 \\
(1.393)\end{array}$ & $\begin{array}{l}0.524^{*} \\
(0.307)\end{array}$ & $\begin{array}{c}1.614 \\
(1.775) \\
\end{array}$ & $\begin{array}{c}-0.236 \\
(1.548) \\
\end{array}$ & $\begin{array}{l}1.379^{\star *} \\
(2.249) \\
\end{array}$ \\
\hline hksa & $\begin{array}{c}0.874^{\star \star *} \\
(0.263) \\
\end{array}$ & $\begin{array}{c}0.501 \\
(1.415) \\
\end{array}$ & $\begin{array}{c}-0.819^{\star *} \\
(0.401)\end{array}$ & $\begin{array}{l}-1.682 \\
(1.552) \\
\end{array}$ & $\begin{array}{c}-1.648^{\star \star *} \\
(0.671)\end{array}$ & $\begin{array}{c}-2.567^{* * *} \\
(1.488) \\
\end{array}$ \\
\hline $\mathrm{pr}$ & $\begin{array}{c}0.005 \\
(0.003)\end{array}$ & $\begin{array}{l}-0.003 \\
(0.004)\end{array}$ & $\begin{array}{l}0.067^{* *} \\
(0.030)\end{array}$ & $\begin{array}{c}0.033 \\
(0.028)\end{array}$ & $\begin{array}{l}0.078^{\star *} \\
(0.040)\end{array}$ & $\begin{array}{c}0.129 \\
(0.029)\end{array}$ \\
\hline prma & $\begin{array}{c}-0.261^{\star \star \star} \\
(0.052)\end{array}$ & $\begin{array}{c}-1.820^{\star \star \star} \\
(0.345)\end{array}$ & $\begin{array}{l}-0.007 \\
(0.016)\end{array}$ & $\begin{array}{c}0.001 \\
(0.018)\end{array}$ & $\begin{array}{c}0.101^{\star * *} \\
(0.034)\end{array}$ & $\begin{array}{c}0.413^{\star \star \star} \\
(0.133) \\
\end{array}$ \\
\hline prsa & $\begin{array}{c}0.200^{\star * *} \\
(0.054) \\
\end{array}$ & $\begin{array}{c}1.759^{\star \star *} \\
(0.344) \\
\end{array}$ & $\begin{array}{c}0.002 \\
(0.011) \\
\end{array}$ & $\begin{array}{l}-0.002 \\
(0.006)\end{array}$ & $\begin{array}{l}-0.414^{*} \\
(0.219) \\
\end{array}$ & $\begin{array}{c}-0.837^{\star * *} \\
(0.211) \\
\end{array}$ \\
\hline $\mathrm{u}$ & $\begin{array}{c}0.037^{\star \star *} \\
(0.008)\end{array}$ & $\begin{array}{c}0.039^{\star \star *} \\
(0.006)\end{array}$ & $\begin{array}{c}-0.132^{\star * *} \\
(0.045)\end{array}$ & $\begin{array}{l}-0.097^{*} \\
(0.057)\end{array}$ & $\begin{array}{c}0.303^{\star \star \star} \\
(0.091)\end{array}$ & $\begin{array}{c}0.232 \\
(0.066) \\
\end{array}$ \\
\hline active & $\begin{array}{c}0.699^{\star \star \star} \\
(0.111)\end{array}$ & $\begin{array}{c}0.296^{\star \star \star} \\
(0.121)\end{array}$ & $\begin{array}{c}0.244 \\
(0.335) \\
\end{array}$ & $\begin{array}{c}0.198 \\
(0.349)\end{array}$ & $\begin{array}{c}2.866^{\star \star \star} \\
(0.827)\end{array}$ & $\begin{array}{c}1.823 \\
(0.757)\end{array}$ \\
\hline aus & $\begin{array}{c}-1.048^{\star \star *} \\
(0.132) \\
\end{array}$ & $\begin{array}{c}-1.069^{\star \star *} \\
(0.129) \\
\end{array}$ & & & & \\
\hline bel & $\begin{array}{c}-0.650^{* * *} \\
(0.061)\end{array}$ & $\begin{array}{c}-0.886^{\star * *} \\
(0.064)\end{array}$ & & & & \\
\hline fin & $\begin{array}{c}-0.583^{\star \star \star} \\
(0.121)\end{array}$ & $\begin{array}{c}-0.744^{\star \star \star} \\
(0.099)\end{array}$ & & & & \\
\hline fra & $\begin{array}{c}-0.237 \\
(0.181) \\
\end{array}$ & $\begin{array}{c}-0.941^{\star * *} \\
(0.182)\end{array}$ & & & & \\
\hline ger & $\begin{array}{l}-0.260 \\
(0.229) \\
\end{array}$ & $\begin{array}{c}-1.084^{\star \star \star} \\
(0.219)\end{array}$ & & & & \\
\hline ire & $\begin{array}{c}-0.527^{\star \star \star} \\
(0.033)\end{array}$ & $\begin{array}{c}-0.577^{\star \star \star} \\
(0.031)\end{array}$ & & & & \\
\hline \multicolumn{7}{|l|}{ ned } \\
\hline swe & $\begin{array}{c}-0.344^{\star \star \star} \\
(0.115) \\
\end{array}$ & $\begin{array}{c}-0.604^{\star * *} \\
(0.097) \\
\end{array}$ & & & & \\
\hline uk & $\begin{array}{l}-0.269^{*} \\
(0.148) \\
\end{array}$ & $\begin{array}{c}-0.890^{\star \star *} \\
(0.148)\end{array}$ & & & & \\
\hline gre & & & $\begin{array}{l}-2.778^{\star} \\
(1.512)\end{array}$ & $\begin{array}{l}-1.455 \\
(1.605)\end{array}$ & & \\
\hline por & & & $\begin{array}{c}-4.905^{\star *} \\
(2.506)\end{array}$ & $\begin{array}{l}-0.060 \\
(0.866)\end{array}$ & & \\
\hline hun & & & & & $\begin{array}{l}-0.313 \\
(0.470) \\
\end{array}$ & $\begin{array}{c}-0.685^{* * *} \\
(0.412)\end{array}$ \\
\hline pol & & & & & $\begin{array}{c}-2.793^{\star \star *} \\
(0.504)\end{array}$ & $\begin{array}{c}-1.937^{\star \star *} \\
(0.525)\end{array}$ \\
\hline constant & $\begin{array}{c}-12.940^{\star \star *} \\
(2.324)\end{array}$ & $\begin{array}{c}-12.404^{\star \star \star} \\
(1.327)\end{array}$ & $\begin{array}{c}11.407 \\
(9.225)\end{array}$ & $\begin{array}{c}11.026 \\
(15.185)\end{array}$ & $\begin{array}{l}-12.908 \\
(29.123)\end{array}$ & $\begin{array}{c}-12.645^{\star * \star} \\
(22.963)\end{array}$ \\
\hline No. obs. & 90 & 90 & 30 & 30 & 30 & 30 \\
\hline $\mathrm{R}^{2}$ & & & 0.9741 & 0.99 & 0.9841 & \\
\hline Wald Chi ${ }^{2}$ & $15039.27^{\star \star \star}$ & $31645.46^{\star \star \star}$ & $2043.28^{\star \star \star}$ & $2705.82^{\star \star \star}$ & $1062.97^{\star \star \star}$ & $1667.41^{\star \star \star}$ \\
\hline
\end{tabular}




\begin{tabular}{|c|c|c|c|c|c|c|}
\hline \multirow{2}{*}{ Machinery } & \multicolumn{2}{|c|}{ North } & \multicolumn{2}{|c|}{ South } & \multicolumn{2}{|c|}{ East } \\
\hline & Model 1 & Model 2 & Model 1 & Model 2 & Model 1 & Model 2 \\
\hline gdp & $\begin{array}{c}0.337^{\star \star \star} \\
(0.108)\end{array}$ & $\begin{array}{l}0.430^{\star \star} \\
(0.193)\end{array}$ & $\begin{array}{c}-2.834^{\star \star \star} \\
(0.979)\end{array}$ & $\begin{array}{c}-3.159^{\star \star \star} \\
(1.012)\end{array}$ & $\begin{array}{c}-0.444^{\star * \star} \\
(0.142)\end{array}$ & $\begin{array}{c}-0.533^{\star \star \star} \\
(0.141)\end{array}$ \\
\hline ma & $\begin{array}{c}0.339 \\
(0.842)\end{array}$ & $\begin{array}{c}0.584 \\
(1.157)\end{array}$ & & & $\begin{array}{l}-1.055 \\
(1.896)\end{array}$ & $\begin{array}{c}-0.988^{\star * *} \\
(0.880)\end{array}$ \\
\hline sa & $\begin{array}{c}-0.221 \\
(0.775)\end{array}$ & $\begin{array}{c}-0.265 \\
(0.978)\end{array}$ & $\begin{array}{c}4.229^{\star \star *} \\
(1.328)\end{array}$ & $\begin{array}{c}4.627^{\star \star \star} \\
(1.369)\end{array}$ & $\begin{array}{c}3.131 \\
(2.112)\end{array}$ & $\begin{array}{c}3.346^{\star \star \star} \\
(1.832)\end{array}$ \\
\hline hk & $\begin{array}{c}0.015 \\
(0.035)\end{array}$ & $\begin{array}{l}-0.027 \\
(0.075)\end{array}$ & $\begin{array}{c}0.511^{\star \star *} \\
(0.121)\end{array}$ & $\begin{array}{c}0.586^{\star \star *} \\
(0.125)\end{array}$ & $\begin{array}{c}2.991^{\star \star *} \\
(0.392)\end{array}$ & $\begin{array}{c}2.820^{\star \star *} \\
(0.410)\end{array}$ \\
\hline hkma & $\begin{array}{l}-0.031 \\
(0.222)\end{array}$ & $\begin{array}{c}-0.261 \\
(0.247)\end{array}$ & $\begin{array}{l}-1.410 \\
(7.119)\end{array}$ & $\begin{array}{l}-2.196 \\
(2.658)\end{array}$ & $\begin{array}{c}-1.448 \\
(1.145) \\
\end{array}$ & $\begin{array}{c}-0.892^{\star \star \star} \\
(1.037)\end{array}$ \\
\hline hksa & $\begin{array}{c}0.218 \\
(0.210)\end{array}$ & $\begin{array}{l}0.321^{\star} \\
(0.175)\end{array}$ & $\begin{array}{c}1.147 \\
(6.926)\end{array}$ & $\begin{array}{c}1.886 \\
(2.483)\end{array}$ & $\begin{array}{c}1.491^{\star \star \star} \\
(0.360)\end{array}$ & $\begin{array}{c}1.095^{\star * *} \\
(0.366)\end{array}$ \\
\hline pr & $\begin{array}{c}0.099^{\star \star \star} \\
(0.012)\end{array}$ & $\begin{array}{c}0.099^{\star * \star} \\
(0.021)\end{array}$ & $\begin{array}{c}0.087 \\
(0.093)\end{array}$ & $\begin{array}{c}0.142 \\
(0.091)\end{array}$ & $\begin{array}{c}0.004 \\
(0.047)\end{array}$ & $\begin{array}{c}-0.015 \\
(0.047)\end{array}$ \\
\hline prma & $\begin{array}{c}-0.209^{\star * *} \\
(0.028)\end{array}$ & $\begin{array}{c}-0.277^{\star \star *} \\
(0.064)\end{array}$ & $\begin{array}{l}-0.049 \\
(0.738)\end{array}$ & $\begin{array}{c}0.025 \\
(0.237)\end{array}$ & $\begin{array}{c}-0.190^{\star \star \star} \\
(0.062)\end{array}$ & $\begin{array}{c}-0.172^{\star \star \star} \\
(0.064)\end{array}$ \\
\hline prsa & $\begin{array}{c}0.143^{\star * *} \\
(0.023) \\
\end{array}$ & $\begin{array}{c}0.208^{\star \star \star} \\
(0.053)\end{array}$ & $\begin{array}{c}-0.099 \\
(0.704) \\
\end{array}$ & $\begin{array}{c}-0.162 \\
(0.198)\end{array}$ & $\begin{array}{c}-0.001 \\
(0.114)\end{array}$ & $\begin{array}{c}0.036^{\star * *} \\
(0.125)\end{array}$ \\
\hline $\mathrm{u}$ & $\begin{array}{l}-0.007 \\
(0.017)\end{array}$ & $\begin{array}{c}0.009 \\
(0.028)\end{array}$ & $\begin{array}{c}-0.313^{\star \star *} \\
(0.071)\end{array}$ & $\begin{array}{c}-0.348^{\star \star \star} \\
(0.077)\end{array}$ & $\begin{array}{c}0.014 \\
(0.058)\end{array}$ & $\begin{array}{c}-0.007 \\
(0.054)\end{array}$ \\
\hline active & $\begin{array}{l}-0.063 \\
(0.121)\end{array}$ & $\begin{array}{c}0.057 \\
(0.193) \\
\end{array}$ & $\begin{array}{c}0.720 \\
(0.447) \\
\end{array}$ & $\begin{array}{c}0.429 \\
(0.475)\end{array}$ & $\begin{array}{c}5.885^{\star \star *} \\
(1.062)\end{array}$ & $\begin{array}{c}5.916 \\
(0.912)\end{array}$ \\
\hline \multicolumn{7}{|l|}{ aus } \\
\hline \multicolumn{7}{|l|}{ bel } \\
\hline fin & $\begin{array}{c}-0.678^{\star \star *} \\
(0.257)\end{array}$ & $\begin{array}{c}-0.572 \\
(0.739) \\
\end{array}$ & & & & \\
\hline fra & $\begin{array}{c}-1.705^{\star \star *} \\
(0.260)\end{array}$ & $\begin{array}{c}-1.697^{\star \star *} \\
(0.470)\end{array}$ & & & & \\
\hline ger & $\begin{array}{c}-1.457^{\star \star \star} \\
(0.386)\end{array}$ & $\begin{array}{c}-1.515^{\star *} \\
(0.669)\end{array}$ & & & & \\
\hline ire & $\begin{array}{c}-0.776^{\star \star \star} \\
(0.147)\end{array}$ & $\begin{array}{c}-0.637^{\star \star *} \\
(0.204)\end{array}$ & & & & \\
\hline ned & $\begin{array}{c}-0.902^{\star \star \star} \\
(0.112)\end{array}$ & $\begin{array}{c}-0.880^{\star * *} \\
(0.281)\end{array}$ & & & & \\
\hline swe & $\begin{array}{c}-0.739^{\star \star \star} \\
(0.219)\end{array}$ & $\begin{array}{c}-0.705 \\
(0.601)\end{array}$ & & & & \\
\hline uk & $\begin{array}{c}-1.268^{\star \star *} \\
(0.244)\end{array}$ & $\begin{array}{c}-1.290^{\star \star *} \\
(0.377)\end{array}$ & & & & \\
\hline gre & & & $\begin{array}{c}-5.346^{\star \star \star} \\
(1.556)\end{array}$ & $\begin{array}{c}-6.739^{\star \star \star} \\
(1.765)\end{array}$ & & \\
\hline por & & & $\begin{array}{c}-5.433^{\star \star \star} \\
(1.616)\end{array}$ & $\begin{array}{c}-6.777^{\star \star *} \\
(1.837)\end{array}$ & & \\
\hline hun & & & & & $\begin{array}{c}0.863 \\
(0.683)\end{array}$ & $\begin{array}{c}1.095^{\star \star \star} \\
(0.700)\end{array}$ \\
\hline pol & & & & & $\begin{array}{c}-2.823^{\star * *} \\
(0.879)\end{array}$ & $\begin{array}{c}-2.422^{* * *} \\
(0.809)\end{array}$ \\
\hline constant & $\begin{array}{c}-11.834^{\star \star \star} \\
(2.234)\end{array}$ & $\begin{array}{c}-18.834^{\star \star *} \\
(6.624)\end{array}$ & $\begin{array}{c}-45.043^{\star \star *} \\
(16.170)\end{array}$ & $\begin{array}{c}-74.116^{\star \star \star} \\
(19.759)\end{array}$ & $\begin{array}{c}-109.528^{\star \star \star} \\
(30.902)\end{array}$ & $\begin{array}{c}-115.569^{\star \star \star} \\
(35.143)\end{array}$ \\
\hline No. obs. & 80 & 80 & 30 & 30 & 29 & $29^{\star \star \star}$ \\
\hline $\mathrm{R}^{2}$ & & 0.9976 & & & 0.9834 & $0.9712^{\star \star \star}$ \\
\hline Wald Chi $^{2}$ & $9580.37^{* \star *}$ & $3018.27^{\star \star \star}$ & $5398.54^{\star \star \star}$ & $7851.54^{\star \star \star}$ & $1289.33^{\star \star \star}$ & $1094.07^{\star *}$ \\
\hline
\end{tabular}




\begin{tabular}{|c|c|c|c|c|c|c|}
\hline \multirow{2}{*}{ Metals } & \multicolumn{2}{|c|}{ North } & \multicolumn{2}{|c|}{ South } & \multicolumn{2}{|c|}{ East } \\
\hline & Model 1 & Model 2 & Model 1 & Model 2 & Model 1 & Model 2 \\
\hline gdp & $\begin{array}{c}0.163 \\
(0.159)\end{array}$ & $\begin{array}{c}0.099 \\
(0.225)\end{array}$ & $\begin{array}{l}-0.306 \\
(0.758)\end{array}$ & $\begin{array}{c}0.182 \\
(0.648)\end{array}$ & $\begin{array}{c}0.700^{\star \star \star} \\
(0.138)\end{array}$ & $\begin{array}{l}-0.137 \\
(0.113)\end{array}$ \\
\hline $\mathrm{ma}$ & $\begin{array}{c}-1.970^{\star \star} \\
(0.953)\end{array}$ & $\begin{array}{l}-2.039 \\
(1.854)\end{array}$ & $\begin{array}{c}-5.946 \\
(6.501)\end{array}$ & $\begin{array}{l}-0.693 \\
(0.840)\end{array}$ & $\begin{array}{c}9.396^{\star \star \star} \\
(1.297)\end{array}$ & $\begin{array}{c}3.166 \\
(2.258)\end{array}$ \\
\hline sa & $\begin{array}{c}3.341^{* * *} \\
(1.222)\end{array}$ & $\begin{array}{c}3.027 \\
(2.068)\end{array}$ & $\begin{array}{c}6.079 \\
(6.698)\end{array}$ & & $\begin{array}{c}-6.416^{\star \star *} \\
(1.000)\end{array}$ & $\begin{array}{l}-1.811 \\
(1.571)\end{array}$ \\
\hline hk & $\begin{array}{c}-0.094 \\
(0.082)\end{array}$ & $\begin{array}{l}-0.128 \\
(0.085)\end{array}$ & $\begin{array}{c}0.077 \\
(0.152)\end{array}$ & $\begin{array}{l}0.213^{\star \star} \\
(0.110)\end{array}$ & $\begin{array}{l}0.407^{\star \star} \\
(0.187)\end{array}$ & $\begin{array}{c}1.150^{* \star *} \\
(0.329)\end{array}$ \\
\hline hkma & $\begin{array}{c}0.034 \\
(0.119)\end{array}$ & $\begin{array}{c}0.165 \\
(0.315)\end{array}$ & $\begin{array}{l}-1.345 \\
(2.884)\end{array}$ & $\begin{array}{c}-0.711 \\
(3.414)\end{array}$ & $\begin{array}{c}-0.800 \\
(2.982)\end{array}$ & $\begin{array}{c}-4.545 \\
(17.100)\end{array}$ \\
\hline hksa & $\begin{array}{c}0.184 \\
(0.130)\end{array}$ & $\begin{array}{c}0.017 \\
(0.350)\end{array}$ & $\begin{array}{c}1.912 \\
(3.116)\end{array}$ & $\begin{array}{c}1.200 \\
(3.588)\end{array}$ & $\begin{array}{l}-1.789 \\
(3.083)\end{array}$ & $\begin{array}{c}3.153 \\
(17.087)\end{array}$ \\
\hline $\mathrm{pr}$ & $\begin{array}{c}-0.119^{\star \star \star} \\
(0.033)\end{array}$ & $\begin{array}{c}-0.093^{\star *} \\
(0.045)\end{array}$ & $\begin{array}{l}-0.032 \\
(0.060)\end{array}$ & $\begin{array}{c}-0.015 \\
(0.059)\end{array}$ & $\begin{array}{c}0.065^{\star \star *} \\
(0.023)\end{array}$ & $\begin{array}{l}-0.002 \\
(0.035)\end{array}$ \\
\hline prma & $\begin{array}{c}-0.012 \\
(0.017)\end{array}$ & $\begin{array}{c}0.037 \\
(0.026)\end{array}$ & $\begin{array}{c}0.179 \\
(0.226)\end{array}$ & $\begin{array}{l}0.403^{* *} \\
(0.177)\end{array}$ & $\begin{array}{c}0.282^{\star \star \star} \\
(0.044)\end{array}$ & $\begin{array}{l}-0.026 \\
(0.036)\end{array}$ \\
\hline prsa & $\begin{array}{l}-0.050 \\
(0.038)\end{array}$ & $\begin{array}{c}-0.031 \\
(0.038)\end{array}$ & $\begin{array}{l}-0.206 \\
(0.229)\end{array}$ & $\begin{array}{c}-0.389^{\star *} \\
(0.176)\end{array}$ & $\begin{array}{c}-0.215^{\star \star \star} \\
(0.039)\end{array}$ & $\begin{array}{c}0.032 \\
(0.079)\end{array}$ \\
\hline $\mathrm{u}$ & $\begin{array}{l}-0.002 \\
(0.019)\end{array}$ & $\begin{array}{c}0.013 \\
(0.030)\end{array}$ & $\begin{array}{l}-0.174^{*} \\
(0.101)\end{array}$ & $\begin{array}{c}-0.209^{\star \star \star} \\
(0.071)\end{array}$ & $\begin{array}{c}0.202^{* * *} \\
(0.038)\end{array}$ & $\begin{array}{l}0.102^{\star} \\
(0.055)\end{array}$ \\
\hline active & $\begin{array}{c}-0.687^{\star \star \star} \\
(0.192)\end{array}$ & $\begin{array}{l}-0.370 \\
(0.259)\end{array}$ & $\begin{array}{l}-0.613 \\
(0.437)\end{array}$ & $\begin{array}{c}-0.711^{\star \star} \\
(0.314)\end{array}$ & $\begin{array}{c}3.210^{\star \star \star} \\
(0.592)\end{array}$ & $\begin{array}{l}1.292^{*} \\
(0.745)\end{array}$ \\
\hline aus & $\begin{array}{l}1.057^{* *} \\
(0.500)\end{array}$ & $\begin{array}{c}-0.104 \\
(0.212) \\
\end{array}$ & & & & \\
\hline bel & $\begin{array}{c}-1.213^{\star \star *} \\
(0.158)\end{array}$ & $\begin{array}{c}-1.316^{\star \star \star} \\
(0.530)\end{array}$ & & & & \\
\hline fin & $\begin{array}{c}2.050^{\star \star \star} \\
(0.809)\end{array}$ & $\begin{array}{c}0.703 \\
(0.800)\end{array}$ & & & & \\
\hline fra & $\begin{array}{c}0.057 \\
(0.566)\end{array}$ & $\begin{array}{c}-1.249^{\star *} \\
(0.599)\end{array}$ & & & & \\
\hline ger & $\begin{array}{c}1.079 \\
(0.766)\end{array}$ & $\begin{array}{c}0.000 \\
(0.680)\end{array}$ & & & & \\
\hline ire & $\begin{array}{c}0.469 \\
(0.507)\end{array}$ & $\begin{array}{c}-0.808^{\star \star \star} \\
(0.177)\end{array}$ & & & & \\
\hline ned & $\begin{array}{c}-0.795^{\star \star \star} \\
(0.148)\end{array}$ & $\begin{array}{c}-0.873^{\star *} \\
(0.382)\end{array}$ & & & & \\
\hline swe & $\begin{array}{l}1.273^{\star \star} \\
(0.622)\end{array}$ & $\begin{array}{c}0.356 \\
(0.606)\end{array}$ & & & & \\
\hline uk & $\begin{array}{c}0.117 \\
(0.431)\end{array}$ & $\begin{array}{l}-0.723 \\
(0.499)\end{array}$ & & & & \\
\hline gre & & & $\begin{array}{c}0.185 \\
(1.897)\end{array}$ & $\begin{array}{l}-0.607 \\
(1.287)\end{array}$ & & \\
\hline por & & & $\begin{array}{l}-0.342 \\
(1.719)\end{array}$ & $\begin{array}{l}-0.490 \\
(1.287)\end{array}$ & & \\
\hline hun & & & & & $\begin{array}{c}0.261 \\
(0.190)\end{array}$ & $\begin{array}{c}-0.605^{\star \star *} \\
(0.243)\end{array}$ \\
\hline pol & & & & & $\begin{array}{c}-2.388^{\star \star *} \\
(0.313)\end{array}$ & $\begin{array}{c}-2.083^{\star \star *} \\
(0.556)\end{array}$ \\
\hline constant & $\begin{array}{c}-28.376^{\star \star *} \\
(6.824)\end{array}$ & $\begin{array}{c}-13.919^{\star \star} \\
(6.280)\end{array}$ & $\begin{array}{c}51.985 \\
(46.012)\end{array}$ & $\begin{array}{c}13.376 \\
(19.005)\end{array}$ & $\begin{array}{c}-74.703^{\star \star \star} \\
(6.142)\end{array}$ & $\begin{array}{c}-33.179^{* \star *} \\
(11.536)\end{array}$ \\
\hline No. obs. & 98 & 98 & 30 & 30 & 30 & 30 \\
\hline $\mathrm{R}^{2}$ & 0.998 & 0.9762 & & & & \\
\hline Wald $\mathrm{Chi}^{2}$ & $12424.79^{\star \star \star}$ & $3203.52^{\star \star \star}$ & $5850.55^{\star \star \star}$ & $6294.31^{* \star \star}$ & $3917.74^{\star \star \star}$ & $1006.12^{\star \star \star}$ \\
\hline
\end{tabular}




\begin{tabular}{|c|c|c|c|c|c|c|}
\hline \multirow{2}{*}{ Minerals } & \multicolumn{2}{|c|}{ North } & \multicolumn{2}{|c|}{ South } & \multicolumn{2}{|c|}{ East } \\
\hline & Model 1 & Model 2 & Model 1 & Model 2 & Model 1 & Model 2 \\
\hline gdp & $\begin{array}{c}0.061 \\
(0.330)\end{array}$ & $\begin{array}{c}-0.374^{\star \star \star} \\
(0.061)\end{array}$ & $\begin{array}{c}7.365 \\
(4.595)\end{array}$ & $\begin{array}{l}29.062^{\star \star} \\
(13.722)\end{array}$ & $\begin{array}{c}0.003 \\
(0.183)\end{array}$ & $\begin{array}{c}-0.098^{*} \\
(0.052)\end{array}$ \\
\hline ma & $\begin{array}{l}3.082^{*} \\
(1.669)\end{array}$ & $\begin{array}{c}0.993^{\star \star \star} \\
(0.121)\end{array}$ & $\begin{array}{c}-19.221^{* * *} \\
(2.801)\end{array}$ & $\begin{array}{c}-14.054 \\
(10.827)\end{array}$ & $\begin{array}{c}2.302^{\star \star \star} \\
(0.851)\end{array}$ & $\begin{array}{l}1.524^{\star \star *} \\
(0.335)\end{array}$ \\
\hline sa & $\begin{array}{c}-1.234 \\
(1.306) \\
\end{array}$ & $\begin{array}{l}-0.039 \\
(0.091) \\
\end{array}$ & $\begin{array}{c}21.530 \\
(15.872) \\
\end{array}$ & $\begin{array}{l}-19.887 \\
(14.888)\end{array}$ & $\begin{array}{l}-0.365 \\
(0.435)\end{array}$ & $\begin{array}{l}-0.133 \\
(0.267)\end{array}$ \\
\hline hk & $\begin{array}{c}0.082 \\
(0.131)\end{array}$ & $\begin{array}{c}0.082^{\star * *} \\
(0.013)\end{array}$ & $\begin{array}{c}-1.193 \\
(1.560)\end{array}$ & $\begin{array}{l}-2.348 \\
(2.602)\end{array}$ & $\begin{array}{c}1.148^{* \star *} \\
(0.306)\end{array}$ & $\begin{array}{l}1.441^{\star \star *} \\
(0.271)\end{array}$ \\
\hline hkma & $\begin{array}{c}0.438 \\
(0.385)\end{array}$ & $\begin{array}{c}-0.068 \\
(0.104)\end{array}$ & $\begin{array}{c}3.303 \\
(8.469)\end{array}$ & $\begin{array}{c}-0.864 \\
(1.798)\end{array}$ & $\begin{array}{c}1.246^{*} \\
(0.720)\end{array}$ & $\begin{array}{c}0.410 \\
(0.293)\end{array}$ \\
\hline hksa & $\begin{array}{l}-0.702^{*} \\
(0.407)\end{array}$ & $\begin{array}{c}0.053 \\
(0.119) \\
\end{array}$ & $\begin{array}{l}-2.488 \\
(2.448) \\
\end{array}$ & $\begin{array}{l}-0.470 \\
(4.910) \\
\end{array}$ & $\begin{array}{c}-2.865^{\star *} \\
(1.364)\end{array}$ & $\begin{array}{c}-1.537^{\star * *} \\
(0.552) \\
\end{array}$ \\
\hline $\mathrm{pr}$ & $\begin{array}{l}-0.004 \\
(0.023) \\
\end{array}$ & $\begin{array}{c}-0.011^{\star \star \star} \\
(0.002)\end{array}$ & $\begin{array}{l}-0.501^{*} \\
(0.274)\end{array}$ & $\begin{array}{c}0.303 \\
(0.746) \\
\end{array}$ & $\begin{array}{c}0.027 \\
(0.029) \\
\end{array}$ & $\begin{array}{l}-0.008 \\
(0.027) \\
\end{array}$ \\
\hline prma & $\begin{array}{l}-0.056 \\
(0.047)\end{array}$ & $\begin{array}{c}-0.063^{\star \star \star} \\
(0.004)\end{array}$ & $\begin{array}{l}-0.137 \\
(0.246)\end{array}$ & $\begin{array}{c}0.166 \\
(0.383)\end{array}$ & $\begin{array}{c}0.044 \\
(0.082)\end{array}$ & $\begin{array}{l}0.070^{\star *} \\
(0.033)\end{array}$ \\
\hline prsa & $\begin{array}{l}-0.047 \\
(0.038)\end{array}$ & $\begin{array}{c}0.061^{\star \star \star} \\
(0.006)\end{array}$ & $\begin{array}{l}-0.463 \\
(0.669)\end{array}$ & $\begin{array}{l}-0.200 \\
(0.711)\end{array}$ & $\begin{array}{l}-0.015 \\
(0.033)\end{array}$ & $\begin{array}{c}-0.113^{\star \star} \\
(0.058)\end{array}$ \\
\hline $\mathrm{u}$ & $\begin{array}{c}0.002 \\
(0.037)\end{array}$ & $\begin{array}{c}-0.012^{\star *} \\
(0.005)\end{array}$ & $\begin{array}{c}0.231 \\
(0.432)\end{array}$ & $\begin{array}{c}1.750^{*} \\
(0.974)\end{array}$ & $\begin{array}{c}0.096^{* * *} \\
(0.034)\end{array}$ & $\begin{array}{l}0.073^{\star *} \\
(0.031)\end{array}$ \\
\hline active & $\begin{array}{c}0.052 \\
(0.720)\end{array}$ & $\begin{array}{c}0.597^{\star \star *} \\
(0.036)\end{array}$ & $\begin{array}{c}5.890^{\star * \star} \\
(2.366)\end{array}$ & $\begin{array}{c}18.941^{\star * *} \\
(6.610)\end{array}$ & $\begin{array}{c}2.250^{\star * \star} \\
(0.530)\end{array}$ & $\begin{array}{c}2.994^{\star * \star} \\
(0.556)\end{array}$ \\
\hline aus & $\begin{array}{c}1.288^{*} \\
(0.791)\end{array}$ & $\begin{array}{c}0.380^{\star * *} \\
(0.079)\end{array}$ & & & & \\
\hline bel & $\begin{array}{c}-1.122^{\star \star \star} \\
(0.310)\end{array}$ & $\begin{array}{c}-0.565^{\star * *} \\
(0.067)\end{array}$ & & & & \\
\hline fin & $\begin{array}{l}2.257^{*} \\
(1.285)\end{array}$ & $\begin{array}{l}0.297^{\star \star} \\
(0.151)\end{array}$ & & & & \\
\hline fra & $\begin{array}{c}0.447 \\
(0.920)\end{array}$ & $\begin{array}{c}0.411^{\star \star \star} \\
(0.147)\end{array}$ & & & & \\
\hline ger & $\begin{array}{c}1.084 \\
(1.083) \\
\end{array}$ & $\begin{array}{c}0.899^{\star * \star} \\
(0.216)\end{array}$ & & & & \\
\hline ire & $\begin{array}{c}1.013 \\
(0.809) \\
\end{array}$ & $\begin{array}{c}-0.344^{\star \star *} \\
(0.083)\end{array}$ & & & & \\
\hline ned & $\begin{array}{c}-0.786^{* *} \\
(0.337) \\
\end{array}$ & $\begin{array}{c}-0.265^{\star \star *} \\
(0.054)\end{array}$ & & & & \\
\hline swe & $\begin{array}{c}1.369 \\
(0.892)\end{array}$ & $\begin{array}{l}0.226^{\star *} \\
(0.097)\end{array}$ & & & & \\
\hline uk & $\begin{array}{c}0.104 \\
(0.635) \\
\end{array}$ & $\begin{array}{c}0.199 \\
(0.140) \\
\end{array}$ & & & & \\
\hline gre & & & $\begin{array}{c}16.754 \\
(10.728)\end{array}$ & $\begin{array}{l}42.553^{\star \star} \\
(21.228)\end{array}$ & & \\
\hline por & & & $\begin{array}{c}22.879^{\star * \star} \\
(8.312)\end{array}$ & $\begin{array}{l}62.208^{*} \\
(33.375) \\
\end{array}$ & & \\
\hline hun & & & & & $\begin{array}{c}-0.213 \\
(0.291)\end{array}$ & $\begin{array}{c}-0.191 \\
(0.193)\end{array}$ \\
\hline pol & & & & & $\begin{array}{c}-2.624^{\star \star *} \\
(0.424)\end{array}$ & $\begin{array}{c}-2.780^{\star * *} \\
(0.377)\end{array}$ \\
\hline constant & $\begin{array}{c}-38.166^{\star * *} \\
(12.091)\end{array}$ & $\begin{array}{c}-13.013^{\star \star \star} \\
(1.272)\end{array}$ & $\begin{array}{c}-361.909 \\
(345.253)\end{array}$ & $\begin{array}{c}-71.349 \\
(159.294)\end{array}$ & $\begin{array}{c}-53.932^{* * *} \\
(19.381)\end{array}$ & $\begin{array}{c}-54.291^{\star * \star} \\
(5.887)\end{array}$ \\
\hline No. obs. & 99 & 100 & 30 & 30 & 28 & 28 \\
\hline $\mathrm{R}^{2}$ & 0.9257 & & & 0.7255 & 0.998 & 0.9986 \\
\hline Wald Chi ${ }^{2}$ & $15023.41^{* * *}$ & $33366.27^{\star \star \star}$ & $415.86^{\star \star \star}$ & $134.99^{\star \star \star}$ & $5735.14^{\star \star \star}$ & $8216.2^{\star \star \star}$ \\
\hline
\end{tabular}




\begin{tabular}{|c|c|c|c|c|c|c|}
\hline \multirow{2}{*}{$\begin{array}{c}\text { Textiles \& } \\
\text { clothing }\end{array}$} & \multicolumn{2}{|c|}{ North } & \multicolumn{2}{|c|}{ South } & \multicolumn{2}{|c|}{ East } \\
\hline & Model 1 & Model 2 & Model 1 & Model 2 & Model 1 & Model 2 \\
\hline gdp & $\begin{array}{l}0.371^{\star *} \\
(0.190)\end{array}$ & $\begin{array}{c}0.291 \\
(0.193) \\
\end{array}$ & $\begin{array}{c}-0.344 \\
(0.879) \\
\end{array}$ & $\begin{array}{c}0.984 \\
(0.886) \\
\end{array}$ & $\begin{array}{l}0.370^{*} \\
(0.220)\end{array}$ & $\begin{array}{c}0.683^{\star \star *} \\
(0.193)\end{array}$ \\
\hline ma & $\begin{array}{c}6.190^{* * *} \\
(1.839)\end{array}$ & $\begin{array}{c}3.930^{\star \star \star} \\
(0.988)\end{array}$ & $\begin{array}{c}0.097 \\
(0.209)\end{array}$ & $\begin{array}{l}0.850^{\star *} \\
(0.440)\end{array}$ & $\begin{array}{c}1.750 \\
(1.452)\end{array}$ & $\begin{array}{c}6.637^{\star \star \star} \\
(1.450)\end{array}$ \\
\hline sa & $\begin{array}{c}-3.853^{\star \star \star} \\
(1.378)\end{array}$ & $\begin{array}{c}-1.680^{\star \star \star} \\
(0.599)\end{array}$ & $\begin{array}{c}2.703 \\
(2.163)\end{array}$ & $\begin{array}{c}-4.562^{\star *} \\
(2.330)\end{array}$ & $\begin{array}{c}2.141 \\
(1.963)\end{array}$ & $\begin{array}{l}-1.744 \\
(1.085)\end{array}$ \\
\hline hk & $\begin{array}{l}-0.001 \\
(0.085) \\
\end{array}$ & $\begin{array}{c}0.010 \\
(0.088) \\
\end{array}$ & $\begin{array}{c}0.375^{\star \star \star} \\
(0.086)\end{array}$ & $\begin{array}{c}0.049 \\
(0.164) \\
\end{array}$ & $\begin{array}{c}0.032 \\
(0.692)\end{array}$ & $\begin{array}{l}-0.429 \\
(0.434) \\
\end{array}$ \\
\hline hkma & $\begin{array}{c}0.423 \\
(0.294) \\
\end{array}$ & $\begin{array}{c}0.123 \\
(0.105) \\
\end{array}$ & $\begin{array}{c}-0.938^{\star *} \\
(0.397) \\
\end{array}$ & $\begin{array}{c}0.790 \\
(0.489) \\
\end{array}$ & $\begin{array}{c}0.648 \\
(0.992) \\
\end{array}$ & $\begin{array}{c}6.112^{\star \star \star} \\
(2.402)\end{array}$ \\
\hline hksa & $\begin{array}{l}-0.541 \\
(0.347)\end{array}$ & $\begin{array}{l}-0.171 \\
(0.130)\end{array}$ & $\begin{array}{l}-0.017 \\
(0.148)\end{array}$ & $\begin{array}{l}-0.168 \\
(0.271)\end{array}$ & $\begin{array}{l}-3.578^{*} \\
(1.938)\end{array}$ & $\begin{array}{c}-10.304^{\star \star *} \\
(2.751)\end{array}$ \\
\hline $\mathrm{pr}$ & $\begin{array}{l}0.068^{\star \star} \\
(0.029)\end{array}$ & $\begin{array}{l}0.057^{\star \star} \\
(0.028)\end{array}$ & $\begin{array}{c}0.008 \\
(0.042)\end{array}$ & $\begin{array}{l}0.105^{\star \star} \\
(0.045)\end{array}$ & $\begin{array}{l}0.154^{\star *} \\
(0.067)\end{array}$ & $\begin{array}{c}0.254^{\star * *} \\
(0.038)\end{array}$ \\
\hline prma & $\begin{array}{c}-0.159^{\star \star \star} \\
(0.037)\end{array}$ & $\begin{array}{c}-0.161^{\star \star \star} \\
(0.031)\end{array}$ & $\begin{array}{c}0.002 \\
(0.010)\end{array}$ & $\begin{array}{c}0.027 \\
(0.033)\end{array}$ & $\begin{array}{c}0.121 \\
(0.082)\end{array}$ & $\begin{array}{l}0.350^{\star \star \star} \\
(0.071)\end{array}$ \\
\hline prsa & $\begin{array}{l}-0.017 \\
(0.048)\end{array}$ & $\begin{array}{l}-0.005 \\
(0.013)\end{array}$ & $\begin{array}{l}-0.100 \\
(0.067)\end{array}$ & $\begin{array}{l}0.150^{*} \\
(0.081)\end{array}$ & $\begin{array}{l}-0.188 \\
(0.124)\end{array}$ & $\begin{array}{c}-0.276^{\star * *} \\
(0.062)\end{array}$ \\
\hline $\mathrm{u}$ & $\begin{array}{l}-0.009 \\
(0.026)\end{array}$ & $\begin{array}{l}-0.012 \\
(0.028)\end{array}$ & $\begin{array}{c}-0.189^{\star \star \star} \\
(0.061)\end{array}$ & $\begin{array}{l}-0.124^{*} \\
(0.066)\end{array}$ & $\begin{array}{c}0.208^{\star \star *} \\
(0.073)\end{array}$ & $\begin{array}{c}0.242^{* * *} \\
(0.049)\end{array}$ \\
\hline active & $\begin{array}{l}-0.201 \\
(0.178)\end{array}$ & $\begin{array}{l}-0.209 \\
(0.206)\end{array}$ & $\begin{array}{l}-0.444 \\
(0.370)\end{array}$ & $\begin{array}{c}0.320 \\
(0.445)\end{array}$ & $\begin{array}{c}2.600^{\star \star \star} \\
(0.913)\end{array}$ & $\begin{array}{c}2.468^{\star \star \star} \\
(0.666)\end{array}$ \\
\hline aus & $\begin{array}{l}1.486^{\star \star} \\
(0.632)\end{array}$ & $\begin{array}{l}1.300^{\star * *} \\
(0.511)\end{array}$ & & & & \\
\hline bel & $\begin{array}{c}-1.524^{\star \star \star} \\
(0.208)\end{array}$ & $\begin{array}{c}-1.646^{\star \star \star} \\
(0.183)\end{array}$ & & & & \\
\hline fin & $\begin{array}{c}2.911^{\star \star \star} \\
(1.004)\end{array}$ & $\begin{array}{c}2.804^{\star \star \star} \\
(0.870)\end{array}$ & & & & \\
\hline fra & $\begin{array}{c}0.307 \\
(0.747) \\
\end{array}$ & $\begin{array}{c}0.085 \\
(0.640) \\
\end{array}$ & & & & \\
\hline ger & $\begin{array}{c}1.066 \\
(0.933)\end{array}$ & $\begin{array}{c}1.088 \\
(0.866)\end{array}$ & & & & \\
\hline ire & $\begin{array}{l}1.411^{\star \star} \\
(0.613)\end{array}$ & $\begin{array}{l}1.159^{\star \star} \\
(0.498)\end{array}$ & & & & \\
\hline ned & $\begin{array}{c}-1.065^{\star \star \star} \\
(0.163)\end{array}$ & $\begin{array}{c}-1.123^{\star \star \star} \\
(0.179)\end{array}$ & & & & \\
\hline swe & $\begin{array}{c}1.783^{\star \star \star} \\
(0.710)\end{array}$ & $\begin{array}{c}1.866^{\star \star \star} \\
(0.665)\end{array}$ & & & & \\
\hline uk & $\begin{array}{l}-0.113 \\
(0.540)\end{array}$ & $\begin{array}{l}-0.202 \\
(0.486)\end{array}$ & & & & \\
\hline gre & & & $\begin{array}{l}-0.430 \\
(1.030)\end{array}$ & $\begin{array}{l}-0.299 \\
(1.194)\end{array}$ & & \\
\hline por & & & $\begin{array}{l}-0.955 \\
(1.152)\end{array}$ & $\begin{array}{l}-1.060 \\
(1.230)\end{array}$ & & \\
\hline hun & & & & & $\begin{array}{c}0.676 \\
(0.777)\end{array}$ & $\begin{array}{l}-0.067 \\
(0.280)\end{array}$ \\
\hline pol & & & & & $\begin{array}{l}-1.077 \\
(0.909)\end{array}$ & $\begin{array}{c}-1.683^{\star \star \star} \\
(0.297)\end{array}$ \\
\hline constant & $\begin{array}{c}-58.072^{\star \star *} \\
(12.152)\end{array}$ & $\begin{array}{c}-53.203^{\star \star *} \\
(9.591)\end{array}$ & $\begin{array}{c}-51.055^{\star \star} \\
(26.421)\end{array}$ & $\begin{array}{l}73.759^{\star *} \\
(37.345)\end{array}$ & $\begin{array}{l}-81.941^{* *} \\
(35.009)\end{array}$ & $\begin{array}{c}-88.401^{* * *} \\
(11.428)\end{array}$ \\
\hline No. obs. & 100 & 100 & 30 & 30 & 30 & 30 \\
\hline $\mathrm{R}^{2}$ & 0.9969 & 0.9943 & & 0.9897 & 0.9624 & 0.9939 \\
\hline Wald Chi ${ }^{2}$ & $10175.4^{\star \star \star}$ & $6000.12^{\star \star \star}$ & $2630.49^{\star \star \star}$ & $1291.33^{\star \star \star}$ & $845.47^{\star \star \star}$ & $4364.49^{\star \star \star}$ \\
\hline
\end{tabular}




\begin{tabular}{|c|c|c|c|c|c|c|}
\hline \multirow{2}{*}{$\begin{array}{l}\text { Transport } \\
\text { equipment }\end{array}$} & \multicolumn{2}{|c|}{ North } & \multicolumn{2}{|c|}{ South } & \multicolumn{2}{|c|}{ East } \\
\hline & Model 1 & Model 2 & Model 1 & Model 2 & Model 1 & Model 2 \\
\hline gdp & $\begin{array}{l}1.300^{* \star *} \\
(0.171)\end{array}$ & $\begin{array}{l}1.222^{\star * *} \\
(0.322)\end{array}$ & $\begin{array}{c}-5.642^{* \star \star} \\
(1.429)\end{array}$ & $\begin{array}{c}-7.507^{* \star *} \\
(1.391)\end{array}$ & $\begin{array}{l}0.944^{* *} \\
(0.422)\end{array}$ & $\begin{array}{c}-0.341^{* \star *} \\
(0.105)\end{array}$ \\
\hline $\mathrm{ma}$ & $\begin{array}{c}-3.520^{\star \star \star} \\
(0.833)\end{array}$ & $\begin{array}{l}2.201^{* *} \\
(0.945)\end{array}$ & $\begin{array}{c}7.970^{\star \star *} \\
(1.519)\end{array}$ & $\begin{array}{c}13.003^{\star \star *} \\
(2.867)\end{array}$ & $\begin{array}{c}-0.757^{\star *} \\
(0.384)\end{array}$ & $\begin{array}{c}-0.824^{\star \star \star} \\
(0.340)\end{array}$ \\
\hline sa & $\begin{array}{c}4.326^{\star \star \star} \\
(0.895)\end{array}$ & $\begin{array}{l}-1.220^{*} \\
(0.740)\end{array}$ & $\begin{array}{c}0.243 \\
(0.224)\end{array}$ & $\begin{array}{c}-5.422^{\star *} \\
(2.302)\end{array}$ & $\begin{array}{c}1.434^{\star \star \star} \\
(0.437)\end{array}$ & $\begin{array}{c}3.305^{\star \star \star} \\
(0.532)\end{array}$ \\
\hline hk & $\begin{array}{c}-0.040 \\
(0.045)\end{array}$ & $\begin{array}{c}0.009 \\
(0.092)\end{array}$ & $\begin{array}{c}0.581^{\star \star \star} \\
(0.153)\end{array}$ & $\begin{array}{c}0.546^{\star \star \star} \\
(0.175)\end{array}$ & $\begin{array}{c}0.634^{\star \star \star} \\
(0.196)\end{array}$ & $\begin{array}{c}0.683^{\star \star \star} \\
(0.198)\end{array}$ \\
\hline hkma & $\begin{array}{l}-0.179 \\
(0.198) \\
\end{array}$ & $\begin{array}{l}0.211^{*} \\
(0.129)\end{array}$ & $\begin{array}{c}0.180 \\
(0.344)\end{array}$ & $\begin{array}{c}-1.622 \\
(4.198) \\
\end{array}$ & $\begin{array}{c}0.053 \\
(0.543) \\
\end{array}$ & $\begin{array}{c}-1.332^{\star \star} \\
(0.557) \\
\end{array}$ \\
\hline hksa & $\begin{array}{l}0.302^{* *} \\
(0.140)\end{array}$ & $\begin{array}{c}-0.224 \\
(0.199) \\
\end{array}$ & $\begin{array}{c}-1.056^{\star *} \\
(0.452) \\
\end{array}$ & $\begin{array}{c}1.898 \\
(4.448) \\
\end{array}$ & $\begin{array}{c}-1.620^{\star \star \star} \\
(0.198)\end{array}$ & $\begin{array}{c}-1.034^{\star *} \\
(0.431) \\
\end{array}$ \\
\hline pr & $\begin{array}{c}-0.148^{\star \star *} \\
(0.014)\end{array}$ & $\begin{array}{c}-0.146^{\star \star *} \\
(0.025)\end{array}$ & $\begin{array}{c}-0.016 \\
(0.018)\end{array}$ & $\begin{array}{l}-0.015 \\
(0.019)\end{array}$ & $\begin{array}{c}0.185^{\star \star *} \\
(0.019)\end{array}$ & $\begin{array}{c}0.089^{\star \star \star} \\
(0.028)\end{array}$ \\
\hline prma & $\begin{array}{c}-0.040 \\
(0.344)\end{array}$ & $\begin{array}{l}-0.671 \\
(0.601)\end{array}$ & $\begin{array}{c}0.034 \\
(0.037)\end{array}$ & $\begin{array}{c}0.315 \\
(0.304)\end{array}$ & $\begin{array}{c}-0.024^{\star * *} \\
(0.003)\end{array}$ & $\begin{array}{c}-0.219^{\star * *} \\
(0.026)\end{array}$ \\
\hline prsa & $\begin{array}{c}-0.001 \\
(0.358) \\
\end{array}$ & $\begin{array}{c}0.665 \\
(0.625) \\
\end{array}$ & $\begin{array}{c}-0.033^{\star *} \\
(0.014)\end{array}$ & $\begin{array}{c}-0.289 \\
(0.296) \\
\end{array}$ & $\begin{array}{l}0.013^{\star} \\
(0.007)\end{array}$ & $\begin{array}{c}0.328^{\star \star \star} \\
(0.043)\end{array}$ \\
\hline $\mathrm{u}$ & $\begin{array}{c}0.041^{* * *} \\
(0.016)\end{array}$ & $\begin{array}{c}0.036 \\
(0.036)\end{array}$ & $\begin{array}{c}-0.376^{\star * \star} \\
(0.098)\end{array}$ & $\begin{array}{c}-0.426^{\star * *} \\
(0.101)\end{array}$ & $\begin{array}{c}0.043 \\
(0.039)\end{array}$ & $\begin{array}{c}0.113^{\star * *} \\
(0.042)\end{array}$ \\
\hline active & $\begin{array}{c}-0.841^{\star \star \star} \\
(0.168)\end{array}$ & $\begin{array}{c}-0.698^{\star \star *} \\
(0.269)\end{array}$ & $\begin{array}{c}0.699 \\
(0.522) \\
\end{array}$ & $\begin{array}{c}0.333 \\
(0.490) \\
\end{array}$ & $\begin{array}{c}5.593^{\star \star *} \\
(0.453)\end{array}$ & $\begin{array}{c}5.901^{* * *} \\
(0.416)\end{array}$ \\
\hline \multicolumn{7}{|l|}{ aus } \\
\hline \multicolumn{7}{|l|}{ bel } \\
\hline fin & $\begin{array}{c}1.795^{\star \star \star} \\
(0.364)\end{array}$ & $\begin{array}{l}1.754^{\star *} \\
(0.737) \\
\end{array}$ & & & & \\
\hline fra & $\begin{array}{c}-2.230^{\star \star \star} \\
(0.508)\end{array}$ & $\begin{array}{c}-2.464^{\star \star \star} \\
(0.925)\end{array}$ & & & & \\
\hline ger & $\begin{array}{c}-2.063^{\star \star *} \\
(0.647)\end{array}$ & $\begin{array}{l}-2.177^{*} \\
(1.217)\end{array}$ & & & & \\
\hline \multicolumn{7}{|l|}{ ire } \\
\hline ned & $\begin{array}{c}-1.910^{\star * *} \\
(0.111)\end{array}$ & $\begin{array}{c}-1.973^{\star * *} \\
(0.208)\end{array}$ & & & & \\
\hline swe & $\begin{array}{c}0.379 \\
(0.325)\end{array}$ & $\begin{array}{c}0.376 \\
(0.648)\end{array}$ & & & & \\
\hline uk & $\begin{array}{c}-1.855^{\star \star *} \\
(0.390)\end{array}$ & $\begin{array}{c}-2.017^{\star \star \star} \\
(0.726)\end{array}$ & & & & \\
\hline gre & & & $\begin{array}{c}-8.577^{\star * \star} \\
(2.121)\end{array}$ & $\begin{array}{c}-12.412^{\star \star \star} \\
(2.076)\end{array}$ & & \\
\hline por & & & $\begin{array}{c}-16.620^{\star \star \star} \\
(3.552)\end{array}$ & $\begin{array}{c}-22.810^{* * \star} \\
(3.823)\end{array}$ & & \\
\hline hun & & & & & $\begin{array}{c}1.632^{\star \star \star} \\
(0.365)\end{array}$ & $\begin{array}{c}0.866^{\star \star \star} \\
(0.180)\end{array}$ \\
\hline pol & & & & & $\begin{array}{c}-2.548^{\star \star *} \\
(0.338)\end{array}$ & $\begin{array}{c}-1.456^{\star \star *} \\
(0.212)\end{array}$ \\
\hline constant & $\begin{array}{c}-43.794^{\star \star *} \\
(3.763)\end{array}$ & $\begin{array}{c}-44.837^{* * *} \\
(7.234)\end{array}$ & $\begin{array}{c}-10.392 \\
(13.326)\end{array}$ & $\begin{array}{c}47.998^{\star \star \star} \\
(15.007)\end{array}$ & $\begin{array}{c}-57.205^{\star \star \star} \\
(13.522)\end{array}$ & $\begin{array}{c}-66.686^{\star \star *} \\
(8.177)\end{array}$ \\
\hline No. obs. & 70 & 70 & 30 & 30 & 24 & 28 \\
\hline $\mathrm{R}^{2}$ & & 0.9978 & 0.9807 & & 0.9988 & 0.9977 \\
\hline Wald Chi ${ }^{2}$ & $12389.65^{\star * \star}$ & $19261.15^{\star \star \star}$ & $2000.34^{\star \star *}$ & $1898.42^{* * *}$ & $37166.7^{\star \star \star}$ & $15380.19^{\star \star \star}$ \\
\hline
\end{tabular}




\begin{tabular}{|c|c|c|c|c|c|c|}
\hline \multirow{2}{*}{$\begin{array}{c}\text { Wood } \\
\text { products }\end{array}$} & \multicolumn{2}{|c|}{ North } & \multicolumn{2}{|c|}{ South } & \multicolumn{2}{|c|}{ East } \\
\hline & Model 1 & Model 2 & Model 1 & Model 2 & Model 1 & Model 2 \\
\hline gdp & $\begin{array}{c}1.200^{\star \star *} \\
(0.249)\end{array}$ & $\begin{array}{c}1.259^{\star \star \star} \\
(0.262)\end{array}$ & $\begin{array}{c}-3.523^{\star \star} \\
(1.679)\end{array}$ & $\begin{array}{c}2.293^{\star \star \star} \\
(0.621)\end{array}$ & $\begin{array}{c}1.190^{\star \star \star} \\
(0.234)\end{array}$ & $\begin{array}{c}1.007^{\star \star \star} \\
(0.220)\end{array}$ \\
\hline ma & $\begin{array}{c}0.237 \\
(0.481) \\
\end{array}$ & $\begin{array}{c}0.306 \\
(0.708)\end{array}$ & $\begin{array}{c}0.336 \\
(1.026)\end{array}$ & $\begin{array}{c}-5.623^{\star * *} \\
(2.010)\end{array}$ & $\begin{array}{l}-0.419^{*} \\
(0.256)\end{array}$ & $\begin{array}{l}-0.442^{*} \\
(0.239)\end{array}$ \\
\hline sa & $\begin{array}{l}-0.449 \\
(0.509) \\
\end{array}$ & $\begin{array}{l}-0.338 \\
(0.884) \\
\end{array}$ & $\begin{array}{c}3.571^{* * *} \\
(1.008)\end{array}$ & $\begin{array}{c}9.241^{* * *} \\
(2.133)\end{array}$ & $\begin{array}{c}5.622^{* * *} \\
(1.134)\end{array}$ & $\begin{array}{c}5.642^{\star * *} \\
(1.050)\end{array}$ \\
\hline hk & $\begin{array}{l}-0.169^{*} \\
(0.093)\end{array}$ & $\begin{array}{c}-0.176^{\star *} \\
(0.089)\end{array}$ & $\begin{array}{c}0.409^{\star * *} \\
(0.137)\end{array}$ & $\begin{array}{c}-0.014 \\
(0.112)\end{array}$ & $\begin{array}{c}-0.190 \\
(0.211)\end{array}$ & $\begin{array}{c}-0.001 \\
(0.196)\end{array}$ \\
\hline hkma & $\begin{array}{c}-0.491^{\star \star \star} \\
(0.175)\end{array}$ & $\begin{array}{c}-0.420^{* * *} \\
(0.171)\end{array}$ & $\begin{array}{c}-0.225 \\
(0.166)\end{array}$ & $\begin{array}{l}-0.722 \\
(0.664)\end{array}$ & $\begin{array}{c}-2.162^{\star * *} \\
(0.511)\end{array}$ & $\begin{array}{c}-2.042^{\star \star \star} \\
(0.477)\end{array}$ \\
\hline hksa & $\begin{array}{c}0.605^{\star \star *} \\
(0.177)\end{array}$ & $\begin{array}{c}0.309^{\star \star *} \\
(0.120)\end{array}$ & $\begin{array}{c}0.097 \\
(0.155) \\
\end{array}$ & $\begin{array}{c}1.184 \\
(0.864) \\
\end{array}$ & $\begin{array}{c}-0.385 \\
(0.348) \\
\end{array}$ & $\begin{array}{c}-0.384 \\
(0.371) \\
\end{array}$ \\
\hline $\mathrm{pr}$ & $\begin{array}{l}-0.013^{*} \\
(0.008)\end{array}$ & $\begin{array}{l}-0.013^{*} \\
(0.007)\end{array}$ & $\begin{array}{c}0.065 \\
(0.049)\end{array}$ & $\begin{array}{l}-0.051 \\
(0.039)\end{array}$ & $\begin{array}{c}0.118^{\star \star \star} \\
(0.016)\end{array}$ & $\begin{array}{c}0.114^{\star \star *} \\
(0.015)\end{array}$ \\
\hline prma & $\begin{array}{c}0.020 \\
(0.015) \\
\end{array}$ & $\begin{array}{l}0.025^{\star} \\
(0.015) \\
\end{array}$ & $\begin{array}{c}-0.064^{* \star *} \\
(0.024)\end{array}$ & $\begin{array}{c}-0.166^{\star \star \star} \\
(0.049)\end{array}$ & $\begin{array}{c}-0.024^{* * *} \\
(0.005)\end{array}$ & $\begin{array}{c}-0.021^{\star * *} \\
(0.005)\end{array}$ \\
\hline prsa & $\begin{array}{c}0.009 \\
(0.009)\end{array}$ & $\begin{array}{c}0.010 \\
(0.015)\end{array}$ & $\begin{array}{c}0.004 \\
(0.012) \\
\end{array}$ & $\begin{array}{c}0.141^{\star \star *} \\
(0.053)\end{array}$ & $\begin{array}{c}-0.220^{\star * *} \\
(0.038)\end{array}$ & $\begin{array}{c}-0.229^{\star * *} \\
(0.037)\end{array}$ \\
\hline $\mathrm{u}$ & $\begin{array}{c}0.080^{* \star *} \\
(0.024)\end{array}$ & $\begin{array}{c}0.083^{* * *} \\
(0.026)\end{array}$ & $\begin{array}{l}-0.212^{* *} \\
(0.109)\end{array}$ & $\begin{array}{c}-0.240^{* \star \star} \\
(0.054)\end{array}$ & $\begin{array}{c}0.291^{* \star *} \\
(0.042)\end{array}$ & $\begin{array}{c}0.282^{* \star *} \\
(0.037)\end{array}$ \\
\hline active & $\begin{array}{c}0.119 \\
(0.183) \\
\end{array}$ & $\begin{array}{c}0.074 \\
(0.192) \\
\end{array}$ & $\begin{array}{c}0.329 \\
(0.605) \\
\end{array}$ & $\begin{array}{c}-0.297 \\
(0.266) \\
\end{array}$ & $\begin{array}{c}4.685^{\star * *} \\
(0.596)\end{array}$ & $\begin{array}{c}4.516^{* \star *} \\
(0.612)\end{array}$ \\
\hline aus & $\begin{array}{c}-1.107^{\star * *} \\
(0.220)\end{array}$ & $\begin{array}{c}-1.001^{\star * *} \\
(0.403)\end{array}$ & & & & \\
\hline bel & $\begin{array}{c}-1.050^{\star \star \star} \\
(0.135)\end{array}$ & $\begin{array}{c}-1.137^{\star * \star} \\
(0.180)\end{array}$ & & & & \\
\hline fin & $\begin{array}{l}-0.359 \\
(0.381) \\
\end{array}$ & $\begin{array}{l}-0.388 \\
(0.718) \\
\end{array}$ & & & & \\
\hline fra & $\begin{array}{c}-3.002^{\star \star *} \\
(0.596)\end{array}$ & $\begin{array}{c}-3.219^{\star * *} \\
(0.705)\end{array}$ & & & & \\
\hline ger & $\begin{array}{c}-3.252^{\star * \star} \\
(0.732)\end{array}$ & $\begin{array}{c}3.389^{\star * \star} \\
(0.911)\end{array}$ & & & & \\
\hline ire & $\begin{array}{c}0.211 \\
(0.318) \\
\end{array}$ & $\begin{array}{c}0.146 \\
(0.456) \\
\end{array}$ & & & & \\
\hline ned & $\begin{array}{c}-1.338^{\star \star *} \\
(0.200) \\
\end{array}$ & $\begin{array}{c}-1.432^{\star \star \star} \\
(0.217)\end{array}$ & & & & \\
\hline swe & $\begin{array}{c}-0.923^{\star * *} \\
(0.310)\end{array}$ & $\begin{array}{c}-0.937^{*} \\
(0.571)\end{array}$ & & & & \\
\hline uk & $\begin{array}{c}-2.257^{\star \star \star} \\
(0.491)\end{array}$ & $\begin{array}{c}-2.473^{\star \star *} \\
(0.555)\end{array}$ & & & & \\
\hline gre & & & $\begin{array}{c}-6.667^{* *} \\
(2.779) \\
\end{array}$ & $\begin{array}{c}-2.712^{\star \star \star} \\
(0.892) \\
\end{array}$ & & \\
\hline por & & & $\begin{array}{c}-12.127^{\star * *} \\
(4.209) \\
\end{array}$ & $\begin{array}{c}-6.716^{\star * *} \\
(1.227) \\
\end{array}$ & & \\
\hline hun & & & & & $\begin{array}{c}3.017^{\star \star \star} \\
(0.462)\end{array}$ & $\begin{array}{c}3.052^{\star \star \star} \\
(0.461)\end{array}$ \\
\hline pol & & & & & $\begin{array}{c}-1.224^{\star *} \\
(0.556)\end{array}$ & $\begin{array}{c}-0.810 \\
(0.545)\end{array}$ \\
\hline constant & $\begin{array}{c}-22.833^{\star * *} \\
(4.514)\end{array}$ & $\begin{array}{c}-26.022^{* * *} \\
(5.667)\end{array}$ & $\begin{array}{c}14.282 \\
(11.985)\end{array}$ & $\begin{array}{c}21.680 \\
(15.325)\end{array}$ & $\begin{array}{c}-150.509^{* * *} \\
(22.591)\end{array}$ & $\begin{array}{c}-143.755^{\star \star \star} \\
(19.272)\end{array}$ \\
\hline No. obs. & 97 & 97 & 30 & 30 & 25 & 25 \\
\hline $\mathrm{R}^{2}$ & 0.9961 & 0.9959 & 0.9972 & & & \\
\hline Wald $\mathrm{Chi}^{2}$ & $45453.48^{\star \star \star}$ & $68577.11^{\star \star \star}$ & $13834.07^{\star \star \star}$ & $10985.07^{\star \star \star}$ & $23284.71^{\star \star \star}$ & $23074.46^{\star * \star}$ \\
\hline
\end{tabular}

'The default regression method is the Prais-Winsten Correlated Panels Corrected Standard Errors with panel-specific AR(1). Standard errors are shown in parenthesis. ${ }^{*},{ }^{* *}$ and ${ }^{* * *}$ represent significance at 10,5 and $1 \%$, respectively. The omitted countries in each group are those with higher real wages: Denmark in the North, Spain in the South and Czech Republic in the East. Whenever the $R^{2}$ is not reported, the FGLS with panel-specific AR(1) and panel correlation was used instead as the Prais-Winsten was not accepted by STATA. The coefficients obtained through the two methods are exactly the same, though the FGLS estimator is more efficient. In the FGLS the $R^{2}$ is not reported as when the GLS parameters are estimated the total sum of squares cannot be broken down as in an OLS regression, making the $R^{2}$ less useful as a diagnostic tool for GLS regressions. Specifically, an $R^{2}$ computed from GLS sums of squares need not be bounded between zero and one and does not represent the percentage of total variation in the dependent variable that is accounted for by the model. Additionally, eliminating or adding variables in a model does not always increase or decrease the computed $R^{2}$ value. 